\title{
Restatements Of Statutory Law: The Curious Case Of The Restatement Of Copyright
}

\author{
Shyamkrishna Balganesh ${ }^{\dagger} \&$ Peter S. Menell ${ }^{\dagger \dagger}$
}

\begin{abstract}
For nearly a century, the American Law Institute's (ALI) Restatements of the Law have played an important role in the American legal system. And in all of this time, they refrained from restating areas of law dominated by a uniform statute despite the proliferation and growing importance of such statutes, especially at the federal level. This omission was deliberate and in recognition of the fundamentally different nature of the judicial role and of lawmaking in areas governed by detailed statutes compared to areas governed by the common law. Then in 2015, without much deliberation, the ALI embarked on the task of restating U.S. copyright law, an area dominated by a detailed federal statute. In so doing, the ALI ignored not just calls to revisit the form and method of its traditional Restatements projects but also the extensive history of the deep mismatch between the Restatements and statutory domains that has informed the working of the enterprise over the course of the last century.

This Article explores the analytical and historical foundations of that mismatch and shows how the Restatement of Copyright reinforces the need to tailor a methodological template and perspective that is sensitive to the nature of statutory interpretation. It explains why perfunctory extension of the common law Restatement model to copyright law produces incoherent, misleading, and seemingly biased results that risk undermining the legitimacy of the eventual product. Finally, the Article explains how the mismatch between the two is capable of being remedied by a series of modest - yet significant — changes, which could allow the project to serve as a template for future statutory Restatements. These include: emphasizing the centrality of the statutory text and relevant interpretive sources, adopting crucial perspectival differences between incremental lawmaking and statutory

$\dagger$ Sol Goldman Professor of Law, Columbia Law School; Adviser, Restatement of Law, Copyright; Member, American Law Institute.

\#† Koret Professor of Law, University of California at Berkeley School of Law; Director, Berkeley Center for Law \& Technology; Faculty Director, Berkeley Judicial Institute; Adviser, Restatement of Law, Copyright; Member, American Law Institute. The authors thank Jane Ginsburg, Tom Merrill, Judge Jon Newman, and David Nimmer for helpful comments and suggestions.

C 2021 Balganesh \& Menell. This is an open access article distributed under the terms of the Creative Commons Attribution-NonCommercial-NoDerivatives License, which permits noncommercial use, distribution, and reproduction, provided the original author and source are credited, and the article is not changed.
\end{abstract}


interpretation, and highlighting the unique legislative process through which the statute was developed.

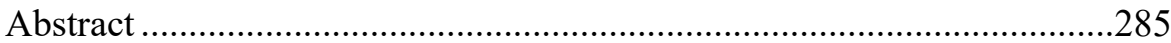

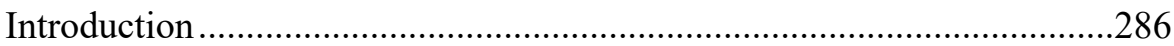

I.The "Restatement" Model and Detailed Statutes: A Perfect Mismatch.292

A. Building the Mismatch: Origins..............................................293

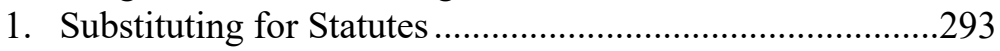

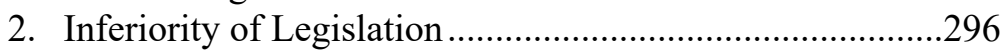

3. Alternative Vehicles: Codes.............................................298

B. The Forgotten History of the Lewis Report of $1924 \ldots \ldots \ldots \ldots \ldots . . . . .301$

1. Types of Statutory Law.....................................................302

2. Rules for Restating Statutory Law .......................................303

C. Restatements and Common Law Statutory Domains ...............305

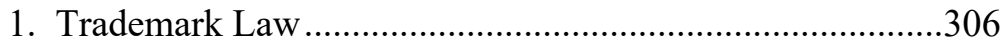

2. Foreign Sovereign Immunity Law .....................................307

D. The Continuing Mismatch: A Conceit of "Voice" and

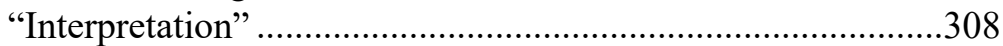

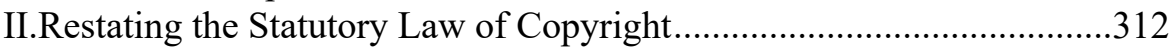

A. Origins: From Principles To Restatement................................313

B. Ignoring and Entrenching the Mismatch ...................................316

1. Ignoring the Mismatch: Putting the Cart Before the Horse

2. Entrenching the Mismatch: A Case Study of the

Restatement's Treatment of the Distribution Right ............324

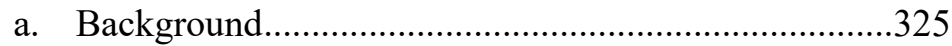

b. Drafting History of the $\S 106(3)$ Distribution Right ...326

c. Putting the $\S 106(3)$ Jurisprudence in Context .............328

d. The Restatement of Copyright Enters the Fray ............329

e. The Adviser Meeting .......................................................333

f. The Restatement of Copyright Makes Matters Worse 334

III.Conclusion: Remedying the Mismatch ................................................337

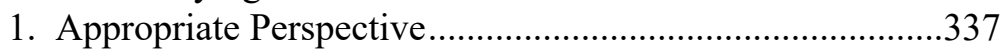

2. Updating the Restatement Template..................................339

3. Contextualizing Preambular Language................................340

\section{INTRODUCTION}

For nearly a century, Restatements of the Law have played a significant role in the American legal landscape. There is hardly any court in the country that has not referred to one of the several Restatements in its opinions. Restatements of the Law are the principal product of the American Law Institute (ALI), an organization of 
legal academics, judges, and lawyers founded in 1923 to clarify, modernize, and otherwise improve the law. ${ }^{1}$ There are today over twenty current (approved and operational) Restatements, each covering a different subject area. ${ }^{2}$ Restatements are introduced to every first-year law student as "general statements of American law" which, although not authoritative as such, are nevertheless "highly persuasive" and routinely cited by courts. ${ }^{3}$

As originally conceived, Restatements were directed at clarifying and simplifying the law through concise, precisely worded statements: so-called "black letter law" or rules. It was therefore no coincidence that the Restatements (and the ALI) emerged during the heyday of juricentrism, where the principal areas of law were seen as judge-made and developed through the application of reason. ${ }^{4}$ Through tersely worded black letter rules, the Restatements aimed to superimpose a degree of order on the complex and generative world of the common law. ${ }^{5}$ The first set of Restatements thus covered torts, contracts, conflict of laws, security interests, agency, judgments, property, restitution, and trusts 6 - common law areas substantively dominated by judge-made law. Conspicuously absent from the list were areas of law governed principally by a statute.

The omission was neither accidental nor unintentional. While it was certainly the post-New Deal era that ushered in a spate of federal legislation covering new fields and supplanting some common law areas, ${ }^{7}$ state and federal legislation proliferated

1. See Founding of the American Law Institute, in The Story of ALI, AM. L. INST., https://perma.cc/4UKX-MEJ4 (last visited Jan. 25, 2021).

2. The ALI lists twenty-two Restatements as current. See Am. L. Inst., Restatements of the Law and Principles of the Law Publications Checklist for Use in 2020 (Nov. 2020), https://perma.cc/3YPVWRQ5. The literature on Restatements is voluminous. For a representative sample, see Kristen David Adams, Blaming the Mirror: The Restatements and the Common Law, 40 IND. L. REV. 205 (2007); Michael Traynor, The First Restatements and the Vision of the American Law Institute: Then and Now, 32 S. ILL. U. L.J. 145 (2007); Herbert Wechsler, The Course of the Restatements, 55 A.B.A. J. 147 (1969); Fred B. Helms, The Restatements: Existing Law or Prophecy, 56 A.B.A. J. 152 (1970); Arthur L. Corbin, The Restatement of the Common Law by the American Law Institute, 15 IowA L. REV. 19 (1929); N.E.H. Hull, Restatement and Reform: A New Perspective on the Origins of the American Law Institute, 8 LAW \& Hist. ReV. 55 (1990); Herbert Wechsler, Restatements and Legal Change: Problems of Policy in the Restatement Work of the American Law Institute, 13 ST. LouIS. U. L.J. 185 (1968); William Draper Lewis, The Value and Use of the American Law Institute Restatements in the Teaching of Law, 7 AM. L. ScH. L. REV. 735 (1930); William Draper Lewis, The First Restatement of the Law and How We Did It, 25 NeB. L. ReV. 206 (1946); George W. Wickersham, The American Law Institute and the Projected Restatement of the Common Law in America, 43 LAW Q. REV. 449 (1927).

3. See, e.g., Peter C. Schanck, A Guide To Legal Research in the University of MiCHIGAN LAW LIBRARY 31 (1978).

4. Cf. Roscoe Pound, Common Law and Legislation, 21 HARV. L. REV. 383, 383 (1908) (noting the "indifference, if not contempt, with which [the] output [of legislation] is regarded by courts and lawyers").

5. AM. L. InST., CAPTURING THE VOICE OF THE AMERICAN LAW INSTITUTE: A HANDBOOK FOR ALI RePorters AND THOSE WHO REVIEW THEIR WORK 36 (2005) [hereinafter ALI, CAPTURING THE VOICE (2005)] (describing the role of black letter rules).

6. See Finding Aids, First Restatement of the Law Records, UnIV. OF PA. LIBRS., https://perma.cc/SVL3-8QJ2 (last visited Jan. 26, 2021).

7. For a general overview, see Nicholas R. Parrillo, Leviathan and Interpretive Revolution: The Administrative State, the Judiciary, and the Rise of Legislative History, 1890-1950, 123 YALE L.J. 266 (2013). 
prior to the New Deal. ${ }^{8}$ These areas simply did not meet the criterion established by the ALI for restatement: resolvable uncertainty. ${ }^{9}$ Indeed, this approach towards statutes was in keeping with the legal zeitgeist of the time, which treated statutes as largely political and thus of an inferior status in the overall skein of legal sources. ${ }^{10}$ Statutory restatements were seen as oxymoronic, reflecting a fundamental mismatch between erudite harmonization of evolving bodies of judge-made law resulting in socalled "black letter law" and actual rules of law resulting from political institutions. ${ }^{11}$

This mismatch was more than just a philosophical position. It had serious implications for the functioning of the ALI, which worked hard to preserve the legitimacy and internal coherence of the restatement enterprise. The mismatch reared its head during one of the earliest Restatement initiatives: the Restatement of Business Associations. Soon after the Restatement of Business Associations was approved by the ALI Council as one of the original restatement projects, its Reporter recognized that the subject matter had numerous - and detailed - statutory provisions that did not fit within the common law restatement model. ${ }^{12}$ This discovery prompted the ALI Council to "fear that 'Business Associations' was a statutory subject, and, as such, incapable of restatement." 13 In an effort to allay this "fear," William Draper Lewis, then Director of the ALI (who also served as reporter for the Business Associations project owing to his specific expertise), produced an elaborate report for the Council wherein he attempted to develop a framework to adapt Restatements to statutory areas. ${ }^{14}$ Despite his efforts to convince the Council that such accommodation was both possible and worthwhile - at least for Business Associations - the project, and the statutory restatement idea, was soon abandoned..$^{15}$

While produced for a very specific purpose, the Lewis Report of 1924 is an insightful, impressive, and prescient work of legal analysis. The Report anticipates the different ways in which statutory law was likely to infiltrate the legal landscape and interact with judge-made law to generate new complexities and challenges for

8. The Field Code movement of the mid- to late nineteenth century produced an abundance of state law codes. See Robert A. Stein, Strengthening Federalism: The Uniform Law Movement in the United States, 99 MinN. L. REV. 2253, 2255 (2015). Congress undertook the codification of federal statutes in 1874. That project gained momentum in the 1920s. See Ralph H. Dwan \& Ernest R. Feidler, The Federal Statutes-Their History and Use, 22 MinN. L. Rev. 1008, 1012, 1021 (1938). In addition, the U.S. Congress directly established new areas of law, such as immigration law, through statutory enactment. See generally KUnAL PARKER, MAKING Foreigners (2015).

9. See infra Part I.A.

10. See Pound, supra note 4, at 383. Pound's observation attempted to capture the prevalent view of the time.

11. See G. Edward White, The American Law Institute and the Triumph of Modernist Jurisprudence, 15 LAW \& HIST. REV. 1, 13 (1997).

12. Resolution No. 38, in Minutes of the Second Meeting of the Council-May 19, 1923, 1 A.L.I. PROC. 28, 40 (1923).

13. William Draper Lewis, Report on Business Associations, 2 A.L.I. Proc. 281, 285-86 (1924) [hereinafter Lewis Report].

14. Id. at 285-88 (detailing the circumstances that generated the report and the manner in which the concern was being addressed).

15. The reasons for the abandonment remain unclear. The project went through three tentative drafts, before being shelved. See Melvin Aron Eisenberg, An Overview of the Principles of Corporate Governance, 48 Bus. LAW. 1271, 1271 (1992). 
Restatements. In addition to identifying these complexities, the Report went one step further and offered the ALI a new framework for Restatements to adopt in addressing each of these statutory complexities. ${ }^{16}$ Sadly, the Report and its suggestions were buried in the annals of time. Despite the proliferation of statutes since that period, coupled with the growing importance of legislation to much - if not all—of American law, the ALI's Restatement initiative never came to embrace areas of American law that were governed fully by a statute, until 2014. In that year, under new leadership, the ALI embarked on a new set of Restatements. ${ }^{17}$ Among the areas chosen for restatement was for the first time a domain of law that was "governed by a detailed federal statute," ${ }^{\prime 18}$ having been the subject of a comprehensive codification effort by Congress in 1976: copyright law.

Copyright law in the United States has always traced its origins back to a federal statute. The U.S. Constitution expressly vests in Congress the power to enact a copyright statute, a power that Congress first exercised in $1790 .{ }^{19}$ The statute was then revised, updated, and replaced on multiple occasions. ${ }^{20}$ Prior to the enactment of the 1976 Act, ${ }^{21}$ U.S. copyright statutes were relatively terse. They identified operative principles in rather general (and abstract) terms, with the result that courts played a critical role in developing its core rules in the exercise of their adjudicative function. ${ }^{22}$ U.S. copyright statutes prior to the 1976 Act were therefore for the most part "common law statutes" that actively delegated lawmaking authority to courts. ${ }^{23}$ The 1976 Act changed this.

In the 1976 Act, Congress consciously asserted its primacy as copyright lawmaker. Areas of copyright law that were hitherto judge-made were codified in

16. Lewis Report, supra note 13, at 357-62.

17. See Press Release, Am. L. Inst., The American Law Institute Announces Four New Projects (Nov. 17, 2014), https://perma.cc/L7H5-N7VX.

18. Richard L. Revesz, Our New Projects, 37 A.L.I. ReP. 3 , 3 (Spring 2015) [hereinafter Revesz, New Projects].

19. U.S. ConST. art. I, \& 8, cl. 8; Copyright Act of 1790, 1 Stat. 124 (1790).

20. For an overview, see Abe A. Goldman, Study No. 1: The History of U.S.A. Copyright Law Revision from 1901 To 1954, in STUDIES PREPARED FOR THE SUBCOMMITTEE ON PATENTS, TRADEMarks, and Copyrights of the CommitTeE on the Judiciary, United States Senate, EIGHTY-SIXTH CONGRESS, FIRST SESSION, PURSUANT To S. RES. 53, ix (1955), https://perma.cc/V3KNXZV6 (noting how comprehensive revisions were carried out in 1831, 1870, and 1909).

21. See Copyright Act of 1976, Pub. L. No. 94-553, 90 Stat. 2541 (1976). The omnibus codification and reform was so sweeping and extensive that Congress delayed its effective date for more than year, until January 1, 1978.

22. See Pierre N. Leval, An Assembly of Idiots, 34 ConN. L. REv. 1049, 1061-62 (2002). Judge Leval captures the old model well:

Under the old model that prevailed until a few decades ago, legislatures would enact brief statutes consisting of a short general description of a statute's prescriptions, often accompanied by a statement of purpose. Over time, uncertainties of application would be litigated before courts. Courts would answer the emerging questions, generally striving in light of experience to give answers the legislature would likely have chosen had it focused on that question.

23. For an elaboration of this idea, see Shyamkrishna Balganesh, Debunking Blackstonian Copyright, 118 YaLe L.J. 1126, 1167-68 (2009); Joseph P. Liu, Regulatory Copyright, 83 N.C. L. Rev. 87, 94-101 (2004). 
the statute, sometimes with significant modification. ${ }^{24}$ In many domains, Congress superimposed basic copyright rules with extensive regulatory mechanisms in an effort to arrive at a compromise between competing interests. ${ }^{25}$ And of course, in many important domains Congress chose to leave judge-made law undisturbed, thereby continuing the delegation of lawmaking authority to courts in specific areas. ${ }^{26}$ Some of these delegations were expressly stated in the statute or legislative history, while others were implicit in Congress's silence. ${ }^{27}$ The Copyright Act of 1976 is thus a statute of "mixed heritage," with each of its provisions having a unique institutional lineage. ${ }^{28}$

Somewhat surprisingly, when the ALI embarked on the Restatement of Copyright, the fundamental mismatch that had so troubled its founders was ignored. The ALI leadership, as well as the newly appointed group of project reporters showed little concern for the idea that the original restatement model was intrinsically unsuited to areas governed comprehensively by statutory provisions. After nominally referring the matter to a committee (which met secretly and invited no input), the ALI Council concluded that there was indeed no mismatch whatsoever between the original restatement format and the demands of areas governed by statutes. ${ }^{29}$ In one fell swoop, the concerns that had motivated the founders of the ALI to requisition the Lewis Report, as well as the Report's recommendations for intricate modifications to accommodate statutory law, were cast aside.

Complicating things further, the Restatement of Copyright reporters chose to engage statutory law in a way not envisioned when the project was initially approved. When originally conceived, the Restatement of Copyright was advertised as limiting itself to areas of judge-made law within copyright. ${ }^{30}$ The Director publicly noted that the project would "principally focus" on matters that the "statute leaves to judicial discretion." 31 Had the Restatement reporters chosen to remain principally focused on judge-made law, its retention of the old format might have been at least somewhat defensible. As the Restatement has developed, however, the Reporters

24. See Shyamkrishna Balganesh, Copyright as Legal Process: The Transformation of American Copyright Law, 168 U. PA. L. REV. 1101, 1158 (2020); Peter S. Menell, In Search of Copyright's Lost Ark: Interpreting the Right To Distribute in the Internet Age, 59 J. COPYRIGHT SOC'Y U.S.A. 1, 31-32 (2011) [hereinafter Menell, Copyright's Lost Ark]; Jessica D. Litman, Copyright, Compromise, and Legislative History, 72 CORNELL L. REV. 857, 857-59 (1987).

25. See, e.g., 17 U.S.C. $\S 111$ (superimposing a statutory licensing regime over the working of the public performance right).

26. See, e.g., id. $\S 107$ (fair use).

27. Whereas the doctrines of fair use, originality, and indirect liability find varying degrees of mention in the statute, the legislative history clearly suggests that Congress intended to preserve judgemade law and judge-made lawmaking in these fields. See 17 U.S.C. $\S \S 107,102(a), 106$; H.R. REP. 941476, at 66 (fair use), 51 (originality), 61 (liability). By contrast, the test for infringement —often referred to as substantial similarity - finds no mention in the statute despite its importance.

28. See generally Peter S. Menell, The Mixed Heritage of Federal Intellectual Property Law and Ramifications for Statutory Interpretation, in INTELleCtUAl PROPERTY AND THE COMMON LAW 63 (Shyamkrishna Balganesh ed., 2013).

29. For the referral to the committee, see January Council Meeting Updates, AM. L. INST. (Jan. 23, 2018), https://perma.cc/E9LG-RTWX [hereinafter January Council Meeting Updates].

30. Revesz, New Projects, supra note 18, at 3.

31. Id. 
have restated not just judge-made copyright law, but also aspects of the copyright statute that had been the subject of extensive (and, at times, contentious) legislative revision, delicate crafting, and compromise. ${ }^{32}$ The ALI Director justified this move on the grounds that even with a detailed statute, courts were nevertheless invested with "broad" "judicial discretion." 33 Notwithstanding its expansion in scope, the Restatement of Copyright project nevertheless continued to adhere to the traditional format, which had been developed and fine-tuned for common law rules. It thus glossed over the importance of both statutory text and statutory interpretation for adjudication in statutory domains. And in the process, it knowingly and overconfidently entered into the dangerous waters that Lewis and his cohort had so "fear[ed]" and recognized as requiring appropriate modification.

As the Restatement of Copyright approaches its first formal vote by the membership of the ALI, this Article reflects on the project's disregard for the fundamental mismatch between the traditional approach to Restatements and statutory law. The Lewis Report presaged the advent of the modern statutory landscape, and with it the centrality of statutory interpretation as a critical part of the adjudicative framework. As we chronicle and demonstrate in this Article, the Restatement of Copyright unfortunately exemplifies precisely the "fear" that the ALI's founders had about integrating statutory areas into Restatements without appropriate modification, and the results of this mismatch threaten to undermine its legitimacy as a useful resource for the field. Furthermore, the Restatement of Copyright ignores the important contemporary precedent, practice, and scholarship surrounding statutory interpretation. ${ }^{34}$ The irony here is that there was a straightforward fix for the problem, one that Lewis astutely recognized at the helm of the ALI a century ago but which the organization's current leadership and project Reporters have inexplicably resisted. ${ }^{35}$

Part I begins with an overview of the fundamental mismatch between restating common law and statutory law that troubled the ALI's founders. This mismatch had a philosophical basis as well as a more practical one, both of which played out in the context of the Restatement of Business Associations and the Lewis Report that sought to develop a framework to accommodate the mismatch. Most importantly, the mismatch continues to plague the form, structure, and direction of the ALI's Restatement enterprise in restricting its ability to directly and honestly engage statutory areas of law where the judicial role differs from what judges do in common law adjudication. Part II then shows how that very mismatch has come to manifest overtly in the Restatement of Copyright. It traces the motivations, origins, and

32. See, e.g., ReStATEMENT OF THE LAW, COPYRIGHT $\S 2$, at 9 (AM. L. InST., Tentative Draft No. 1, Apr. 8, 2020), [hereinafter Restatement Tentative Draft No. 1 (2020)] (dealing with "Types of Works Protected" covered squarely by $\S 102$ (a) of the copyright statute).

33. Richard L. Revesz, Restatements and Federal Statutes, 38 A.L.I. ReP. 3 , 3 (Spring 2016) (offering this justification on the grounds of "discretion") [hereinafter Revesz, Federal Statutes].

34. See, e.g., Robert A. Katzmann, Judging Statutes (2014); William N. ESkRidge, JR., Philip P. Frickey \& Elizabeth Garrett, Legislation: Statutes and the Creation of Public POLICY (3d ed. 2001); William N. Eskridge, Jr. \& Philip P. Frickey, Statutory Interpretation as Practical Reasoning, 42 STAN. L. REV. 321 (1990).

35. See infra Part I.B. 
evolution of the project to show how the mismatch developed within the Restatement and entrenched itself to the detriment of the project. The Article concludes by offering a modest proposal to remedy the mismatch, along precisely the lines that Lewis advocated in 1924, updated to reflect the modern understanding of statutory interpretation.

\section{THE "RESTATEMENT" MODEL AND DETAILED STATUTES: A PERFECT MISMATCH}

Established in 1923 by an elite group of legal scholars, judges, and lawyers, the American Law Institute (ALI) saw itself as an organization dedicated to the task of law reform, or the "improvement of the law and its administration." ${ }^{36}$ This core mission was to be realized through the instrumentality of the "Restatements of the Law," ${ }^{37}$ designed to be "at once analytical, critical and constructive." ${ }^{38}$ Restatements of the Law thus became synonymous with the ALI and its functioning, and while the ALI would eventually embark on a series of additional law reform initiatives in due course, the Restatement enterprise has always remained its core contribution.

From its very inception, however, the ALI's founders had a specific vision for what the Restatements of the Law were meant to achieve, and the precise form and manner in which they were to go about realizing these objectives. ${ }^{39}$ While much of this was a product of its time - the ALI's founders were anchored in the unique conceptions of law and legal sources that characterized mainstream legal thinking in the first quarter of the twentieth century - a large part of it was also intricately tied to the founders' view of the ALI's mission and potential contribution to American law. And while the legal thinking has certainly evolved over time, the ALI's original mission continues to inform the ALI's functioning to this day.

Statutory law-statutory texts as well as subjects governed principally by legislation-was consciously relegated to the peripheries of the Restatement enterprise. As this Part shows, this was a direct consequence of the ALI's conception of its core function: resolving the uncertainty and complexity of American law, a belief that the organization continues to embrace. The form, structure, and style of the Restatements of Law were motivated in their entirety by this commitment to simplification and clarification, which saw little value in directly engaging statutory texts, either descriptively or critically. The ALI viewed those statements of law for the most part as both clear and certain, and as areas where "improvement" (i.e., reform) necessitated a more direct engagement with questions of political economy. This avoidance of the statutory realm generated a good amount of debate in the early

36. Report of the Committee on the Establishment of a Permanent Organization for the Improvement of the Law Proposing the Establishment of an American Law Institute, 1 A.L.I. Proc. 1, 4 (1923) [hereinafter Founding Committee Report]. The committee that produced this report (the "founding committee" or "founders"), consisted of some of the most eminent judges, law professors, and lawyers of the time. See id. at vi.

37. Id. at 13 .

38. Id. at 14

39. Id. at 19 (noting that "general uniformity of type throughout the restatement is important"). For an elaboration, see $i d$. at $19-22$. 
days of the ALI. It manifested in a methodological controversy surrounding the Restatement of the Law of Business Associations, contributing to the eventual abandonment of that project and nearly a century of steering clear of statutory restatements. This Part unpacks the analytical roots and historical bases of this mismatch to show that it is woven deep into the fabric of the Restatements of Law, and remains relevant in the twenty-first century.

\section{A. BuILding The Mismatch: Origins}

Even though the ALI was established as a law reform organization dedicated to the improvement of the law and its administration through Restatements of the Law, its founders" conception of "law reform" and "law" was narrow. This approach actively sidelined statutory law and jurisprudence within the Restatement initiative, a move which at the time was seen as both unproblematic and indeed analytically desirable.

\section{Substituting for Statutes}

To justify the need for a law reform organization such as the ALI and its idea of restating the law, its founders argued that U.S. law at the time was characterized by an "uncertainty and complexity." 40 They attributed much of this to the failings of judge-made law where there existed a "lack of general agreement on fundamental principles" and the use of "loose legal terminology." uncertainty was therefore an inevitable reality of the common law process, which dominated the legal landscape in the first quarter of the twentieth century. ${ }^{42}$ Since courts were never tasked with organizing the operative principles under which they decided cases, nor with stating these principles, the ALI saw its role as offering the common law a method of organizing its functional "general principles": Restatements of the Law. ${ }^{43}$

All the same, the ALI's founders recognized that the other primary sources of law-federal and state statutes - did not suffer from the same problems as judgemade law. Yet here, and in relation to these statutes, the ALI's approach to justifying its own task was two-fold.

First, it argued that judge-made law — and not statutes - dominated the landscape of legal sources. To the ALI at the time, "[m]uch of [the] law is not expressed in statutory form" but instead "all, or nearly all, of law on many subjects is expressed with binding authority only in the recorded decisions of the courts." 44 As explained further below, this observation was more than just a statement of fact, but instead represented a broader position on what binding authority entailed. On the factual

40. Id. at 8 .

41. Id. at 68 .

42. Something that the Founding Committee Report acknowledged but deflected away. See id. at 70 (discussing the process of distinguishing precedent and the volume of reported decisions).

43. $I d$. at 21

44. Id. at 66 . 
side of the claim, however, the argument was that no statute was sufficiently detailed to govern on its own. Instead, statutes were always based on rules created by courts, and thus inevitably relied on judge-made law analogous to the traditional common law. As the ALI's founding committee emphasized:

Practically all statutes relating to the substantive law contain one or more provisions sufficiently general to raise a doubt as to their proper application in some cases. Such a doubt can be resolved only by the decision of the courts. Many statutory provisions indeed are merely statements of more or less general principles of law, and the major part of the law pertaining to the subject with which such statutes deal consists of rules for the application of these principles developed by the courts by a process similar to that by which common law principles are developed. These rules indeed form the common law pertaining to the statute. ${ }^{45}$

Statutes were themselves therefore products of, and reliant on, the common law. In other words, most - if not all—statutes were "common law statutes." unclear from the committee's report whether they drew their analysis from any particular statutes. All the same, a statute such as the Sherman Act of 1890 might have been what motivated the committee's characterization. ${ }^{47}$ The New Deal era, following tumultuous changes in political, administrative, and legal institutions, ushering in a broader range of new statutes, was still a decade away.

What is clear in this observation, however, is that the ALI saw the growth of judge-made law as an inevitable reality of the American legal landscape, despite the prevalence of statutes. Inevitable, in the sense that it was the courts and their application of legal directives to factual disputes that produced the general principles that rationalized legal doctrine. Even when statutes contained "more or less general principles," those principles were less useful than the "principles developed by the courts" in the common law method. ${ }^{48}$

It is important to explore why the ALI founders believed that "restating" legislative general principles was of less utility than restating those of the common law. And here we come to the second reason proffered by the ALI's founders for its approach to restatements of law. Statutory provisions of the time, they claimed, were invariably "conflicting and badly drawn," which produced unnecessary confusion. ${ }^{49}$ Somewhat boldly, the ALI went one step further in its diagnosis of the reasons:

The poor draftsmanship which mars many of our statutes is not the fault of members of our legislatures. It is principally due to the erroneous idea, until recently prevalent among the members of the legal profession, that any lawyer is competent to draft a

45. Id. at 67

46. See Leegin Creative Leather Prods., Inc. v. PSKS, Inc., 551 U.S. 877, 899-900 (2007) (identifying the Sherman Act as a common law statute); Frank Easterbrook, Statutes' Domains, 50 U. CHI. L. REV. 533, 544 (1983) (describing common law statutes as statutes "that effectively authorize courts to create new lines of common law").

47. See, e.g., Founding Committee Report, supra note 36, at 99.

48. Id. at 67.

49. Id. at 69 . 
statute. The art of good legislative drafting, like any other art, is mastered only by practice under the tutelage of experts. ${ }^{50}$

The "experts" that the committee hints at reflected the ALI's elitist vision, one that historians of the organization readily acknowledge as intricately tied to the "status" criteria and distinctions that existed in the legal profession of the time. ${ }^{51}$

Thus, the ALI saw statutes as needing common law development to address their inherent imprecision. What is noteworthy is that the committee made no mention of interpretation in its discussion of the distinction and interaction between judge-made law and a statute's content. The omission is perhaps not conscious given the state of the field at the time, ${ }^{52}$ yet it reveals the institutional dimensions of the American legal landscape that the ALI saw as needing order and organization. Judge-made law was both inevitable and in some implicit sense desirable in all domains. It was therefore the omnipresence of judge-made law that the founding committee used to justify the need for the ALI. Statutes were neither central nor particularly important to the ALI's mission.

The ALI set out to bring about order, organization, and clarity to the morass of judge-made law through the task of restating the law. The Restatements of Law were to embody and isolate "statement[s] of the principles of law," 53 drawn from judicial decisions in a domain. Yet, in describing the form that such statements of principle were to take, the ALI's founding committee turned to the very source that it had questioned and advanced an idea that has since been carried forward in the working of the ALI: "[t]he statement of principles should be made with the care and precision of a well-drawn statute." 54

This observation further supports the notion that the ALI considered existing statutes to be poorly drafted; hence the contrast to a "well-drawn" statute. Additionally, it reveals how the cure to uncertainty and complexity was believed to be found in a commitment to "care and precision" in organization and draftsmanship. ${ }^{55}$ Lastly — and perhaps most importantly—it highlights the ALI founders' belief that Restatements of Law should play the role of a substitute statute, structurally speaking. This last point deserves unpacking.

In emphasizing that the Restatements were to mimic the working of a successful statute, the founding committee assumed that a "well-drawn statute" was indeed a possibility, even if only a theoretical one at the time. Indeed, they felt the existence

50. Id. at $69-70$.

51. See White, supra note 11, at 2,21 (describing the status dimension of the legal profession at this time as "signified by a concern among elite members of the bar that the proliferation of lawyers from 'immigrant' backgrounds and less distinguished law schools was undermining the quality of legal services").

52. Cf. Philip P. Frickey, From the Big Sleep To the Big Heat: The Revival of Theory in Statutory Interpretation, 77 MINN. L. REV. 241, 242-56 (1992) (tracing the intellectual history of statutory interpretation as a field of study in the legal academy).

53. Founding Committee Report, supra note 36, at 19.

54. Id. (emphasis added).

55. Id. at 28 . 
of such a statute to be desirable in the abstract, but unrealizable in practice. ${ }^{56}$ While they were opposed to statutory codification owing to its lack of flexibility and adaptability ${ }^{57}$ they were in favor of a flexible quasi-statute that could be updated and revised periodically without the baggage of the political process. ${ }^{58}$ The statute was the idealized form of law that the ALI's restatement efforts had to try and mimic, in pursuit of its core goal of clarifying and simplifying the law; at the same time, however, the simplification needed to be within the control of courts and, in the process, the ALI. Restatements were therefore adaptable quasi-statutes produced by experts knowledgeable in their fields, devoid of all the political demerits of real legislation. ${ }^{59}$

The ALI's founding therefore reveals something of a love-hate relationship between the Restatements and statutes: a theoretical love for the care and precision that statutory text was capable of offering as a model, but a practical contempt for actual statutes and the statutory process as they existed (and might still exist). The Restatements of Law were seen as functional substitutes for legislation, justified by the fecundity of judge-made law. Given their desired status as such, it is no surprise that the founding committee saw both the product and process of legislation that existed at the time as deeply problematic, leading them to conclude that their "examination of the causes of the present uncertainty of the law shows conclusively the need of a restatement of the law." 60

\section{Inferiority of Legislation}

Quite independent of needing to undermine statutes to emphasize the centrality of judge-made law, there existed an additional reason for the ALI's early disenchantment with statutes, one that had its roots in the theory of law that prevailed through the first quarter of the twentieth century. To lawyers, judges, and scholars of the time, statutes were inferior sources of law. The origins of this view can be traced to the days of classical legal thought (for example, legal formalism), which sought to emphasize the centrality of reason - and a scientific method - to the study and analysis of law. ${ }^{61}$ Judicial decisions were seen as emanating from reasoned argument and thus driven by foundational principles. By contrast, legislation was

56. The relationship between the ALI's founders and the codification movement is complex and has been the subject of some scholarly controversy. For an overview, see Adams, supra note 2, at 22729.

57. Founding Committee Report, supra note 36, at 28 ("[W]e are opposed to any attempt at the general codification of the law in the usual sense of the word."). See also White, supra note 11, at 11-12.

58. White, supra note 11, at 13 (observing how the ALI's founders held the view that "even Congress produced undisciplined, politicized reform").

59. Id. (noting how the rejection was motivated by a strategic interest in "preserving judicial" control over the subjects being restated).

60. Founding Committee Report, supra note 36, at 13.

61. Christopher Columbus Langdell, Dominant Opinions in England During the Nineteenth Century in Relation To Legislation as Illustrated by English Legislation, or the Absence of It, During That Period, 19 HARV. L. REV. 151, 151 (1906) (adopting the view that legislation is not law). 
understood as fraught with the problems of the political process and thus hardly the embodiment of law. ${ }^{62}$

In 1908, Roscoe Pound meticulously analyzed the basis of this attitude, which he described as an "indifference" and at times even "contempt" for legislation. ${ }^{63} \mathrm{He}$ noted how this attitude made it "fashionable to preach the superiority of judge-made law." 64 A few years prior to the founding of the ALI, Pound developed this argument even further, detailing numerous ways in which this disdain manifested itself in the actual working of courts and lawyers. ${ }^{65}$ Benjamin Cardozo echoed the same observations a few years after Pound, noting how lawyers wedded to the common law "view[ed] statutes with a distrust." roles in the founding and initial years of the ALI, and it was therefore not surprising that the attitudes they described as prevalent among lawyers and judges not only influenced but indeed dominated the founding of the ALI. ${ }^{67}$

As already noted, in an effort to emphasize the virtues of the Restatements, the ALI's founding committee saw statutes as lacking both predictability and flexibility. Insofar as they were loosely worded, they were criticized as lacking the precision needed for the functioning of the law. ${ }^{68}$ Simultaneously, the legislative process through which statutes were updated was seen as laborious and political, undermining their flexibility. As the legal historian Edward White has argued, this was, however, only a partial explanation. Another crucial reason for the ALI's disdain of statutes, he argues, was strategic: the "interest in preserving judicial as distinguished from legislative control over common law subjects." ${ }^{69}$ Judges, scholars, and lawyers were seen as able experts to be invested with the task of law reform; while legislators were considered lacking the intellectual abilities to realize that goal. Thus in its actual engagement with statutes, the ALI perpetuated the attitude towards statutes of which Pound and Cardozo had warned.

Viewed against this backdrop, the ALI founding committee's statements about the deficiencies of existing statutory law take on a new dimension. Explaining how the common law's disdain for statutes manifested in the actual working of courts, scholars, and lawyers, Pound identified two principal forms of resistance towards legislation. ${ }^{70}$ The first was the declaratory approach, which viewed statutes as doing no more than declaring pre-existing common law rules. In this approach, courts refused to acknowledge that statutes could alter common law doctrines, and instead

62. Indeed, copyright law was no exception to this phenomenon. See EATON S. Drone, A TREATise on the LAW OF PROPERTY IN INTELlectual Productions, at v (1879) (deriding copyright legislation as having been drawn by "incompetent persons").

63. Pound, supra note 4, at 383.

64. Id. at 383-84.

65. Roscoe Pound, The Spirit of the Common Law 99 (1921) (“The lawyer's theory leads him to pay scant attention to legislation or to mold it and warp it to the exigencies of what he regards as the real law.").

66. Benjamin N. CARdozo, The Paradoxes of Legal SCIENCE 9-10 (1928)

67. Indeed, both were on the founding committee that formed the ALI. See Founding Committee Report, supra note 36 , at vi.

68. Id. at 23 .

69. White, supra note 11 , at 13 .

70. See Pound, supra note 4, at 385 . 
read the text of the statute narrowly even in the face of contrary legislative intent. As Pound put it, courts and scholars "made statutes yield to their juristic ideas in the very teeth of legislative intent," effectively amounting to a declaration of "legislative incompetence to deal with ordinary legal relations." ${ }^{, 71}$ The second was the approach of silence, wherein a statutory text that was seen as changing (rather than declaring) the law was cabined to its narrowest formulation and therefore seen as necessarily silent or inapplicable to an important issue. Principles emanating from statuteseven when unambiguously apparent — were treated as one-off derogations rather than as themselves contributing to the body of generally applicable law. ${ }^{72}$

We see the ready deployment of both approaches in the founding committee's derisive observations about statutory law. ${ }^{73}$ The declaratory approach is perhaps most apparent in the committee's observation that the general principles identified in a statute were themselves the product of judicial decisions, representing the "common law pertaining to the statute." 74 Implicit in this characterization was the conclusion that courts should therefore continue to assume primary responsibility for these principles, despite the presence of the statute, which was the ultimate goal of the declaratory approach. The silence approach is readily seen a few pages later in the Founding Committee Report. Speaking of badly drawn statutes, the committee noted that "the possible application of the provisions of the statute to conditions wholly apart from those which gave rise to the demand for the legislation may be for years a prolific source of uncertainty." ${ }^{, 75}$ Statutes were also criticized for failing to pay attention to the "collateral effects" of their immediate application. ${ }^{76}$ Implicit in both observations was the idea that statutes were narrowly drawn and that legislation routinely failed to anticipate much beyond the immediate problem that motivated it.

Statutes were therefore considered a substantively inferior source of law. This inferiority was qualitatively different from the mere identification of statutes as uncertain and complex, for those deficiencies could - in principle at least-be remedied through appropriately trained legislators. The inferiority was instead an implicit recognition that statutes were in an important sense not real law, but instead an intermediate aberration that courts - and only through them, the Restatementsneeded to countenance and deal with in the process of developing the real law. As discussed further below, this presumptive inferiority continues to shape conversations around statutory areas within the ALI even today, with the Restatement of Copyright being the prime example.

\section{Alternative Vehicles: Codes}

Despite the ALI's early belief in the inadequacy and inferiority of legislation, its founders nevertheless saw some role for the organization in statutory reform-just

71. Pound, supra note 65 , at $106-07$.

Pound, supra note 4, at 385-86.

See supra text accompanying note 50.

Founding Committee Report, supra note 36, at 67.

Id. at 69 .

Id. 
as long as it did not involve the restatement enterprise. Having identified "conflicting and badly drawn statutes" as contributing to the uncertainty and complexity of American law, ${ }^{77}$ the ALI could hardly be seen as failing to address statutes in its commitment to improving the law. Its principal vehicle for dealing with statutes was the idea of "model codes."

The ALI embarked on its first model code project very shortly after its founding, in 1925. The subject was Criminal Procedure. ${ }^{78}$ The ALI appointed a special committee to examine whether the ALI "should undertake [to restate] either the substantive or the procedural criminal law." ${ }^{, 9}$ This committee recommended that the ALI produce a "restatement of the substantive law of crimes," arguing that criminal law suffered from the same problems as most of private law ${ }^{80}$ The statutory status of criminal law in most states was irrelevant, since it was "in the application of ... common law principles in criminal law, as in the application of common law principles in the civil law, that most of the uncertainties and inconsistencies appear." $" 81$ As for criminal procedure, the special committee was more circumspect. While acknowledging that this area too could use restating, it nevertheless insisted that the restatement exercise was insufficient because the law needed "reformation and simplification," which could be achieved through "important statutory changes." ${ }^{82}$ The committee therefore advocated for a "code of criminal procedure" but insisted that the drafting be done by another organization:

We do not suggest that the Institute undertake the preparation of a draft of a code of criminal procedure for the reason that such a code is primarily legislative in character rather than a restatement of existing law, and the Institute was founded and its present funds secured primarily to make a restatement of the common law. ${ }^{83}$

Legislation was reformative and as a result qualitatively different from the restatement initiative. Yet, soon after the committee submitted its report, the ALI resolved to undertake the drafting of the code on its own at the insistence of the American Bar Association, the American Institute of Criminal Law and Criminology, and the Association of American Law Schools. ${ }^{84}$ The ALI's Model Code of Criminal Procedure was produced between 1925 and 1930, and met with significant success, coming to be adopted by numerous state legislatures. This success in turn prompted the ALI to embark on a slew of additional model code projects, each of which was understood to be unambiguously prescriptive in content

77. Id. at 69

78. See Code of Crim. Proc. (Am. L. Inst. 1930).

79. Report To the Council by the Committee on a Survey and Statement of the Defects in Criminal Justice, 3 A.L.I. PROC. 439, 441 (1925).

80. Id. at $488-89$.

81. Id. at 489 .

82. Id. at 490

83. Id. at 492 .

84. Herbert F. Goodrich, The Story of the American Law Institute, 3 WaSH. U. L.Q. 283, 296 (1951). 
(i.e., reformative), but with provisions that "read easily and well and [were] understandable." $" 85$

Perhaps the most successful of the ALI's model codes was the Model Penal Code, adopted in 1962. ${ }^{86}$ Recall that the special committee report on criminal justice reform had advanced the idea that substantive criminal law was ripe for restatement, since it was rife with common law principles that dominated the landscape. Yet, that initiative never took off. After the special committee's recommendation, the ALI considered simultaneously restating substantive criminal law together with a model code on the subject but eventually abandoned that idea as well; it concluded that it would be "wasteful" to prepare a Restatement, when a Code would soon follow that would not just "be a statement of what the law is; [but] . . of what it should be."

Model codes emerged as the ALI's preferred vehicle for dealing with areas governed by statute, in recognition that the organization's intervention needed to be unambiguously reformative and prescriptive, rather than hidden behind the declaratory account of the common law that melded the is-ought distinction.

Model uniform codes were not the only form of codes that the ALI produced. Whereas model codes were directed at state legislatures, in due course the ALI's code-based interventions extended to federal statutory domains as well. The most prominent example here was the Federal Securities Code, produced by the ALI over the course of nearly a decade. ${ }^{88}$ Attempting to simplify and consolidate an area characterized by multiple federal enactments, the Code quickly received the approval of the ALI and the bar. Yet, it failed to persuade Congress and was never enacted into law. ${ }^{89}$ Unlike model codes, which were marketable to multiple states for adoption, federal codes catered to a single consumer, and thereby ran the risk of being immensely wasteful projects for the ALI to invest in without a guarantee of enactment. It is perhaps for this reason that the ALI has not approved a federal codification project since the securities code was finalized in 1980 .

Most importantly though, the ALI's embrace of codification and the proliferation of this type of reform intervention within the ALI served an important demarcation function for its Restatements: It allowed the Restatement enterprise to retain its aloofness from statutes and focus instead on the judicial role in isolation. Directly engaging statutes was left to the codification projects, and Restatements of the Law focused on non-statutory law—both stylistically and substantively.

85. Id. at 295 .

86. Herbert Wechsler, Codification of Criminal Law in the United States: The Model Penal Code, 68 Colum. L. REV. 1425, 1426 (1968).

87. Report of the Advisory Committee on Criminal Justice to the Council, 12 A.L.I. Proc. 369, 379, $382(1935)$.

88. For an overview from its Reporter, see Louis Loss, The American Law Institute's Federal Securities Code Project, 25 Bus. Law. 27 (1969). For a contrary view, see Lewis D. Lowenfels, The Case Against the Proposed Federal Securities Code, 65 VA. L. REV. 615 (1979).

89. Stephen J. Choi, Company Registration: Toward a Status-Based Antifraud Regime, 64 U. CHI. L. REV. 567, 568-69 (1997). 
From its very inception, the ALI's Restatement initiative developed with an unconcealed antipathy - if not disdain - for statutes. The form of the Restatements as well as their voice and tone were built around this antipathy, which became less obvious over time. And principally for this reason, the Restatements of Law stayed away from subjects that were unambiguously governed by statutory law. Indeed, this mismatch between the Restatements and statutes was more than just an abstract consideration. Instead, it would form the basis for an instructive episode in the lifecycle of one of the ALI's earliest restatements.

\section{B. The Forgotten History OF THE LEWIS REPORT OF 1924}

The mismatch between Restatements of Law and statutory subject areas was more than just theoretical and manifested in the realities of the ALI soon after the organization was formed. The particular episode that brought the mismatch to the surface was an early Restatement project approved by the ALI Council: the Restatement of the Law of Business Associations. ${ }^{90}$ The details of this episode have been all but forgotten by the ALI. Yet its relevance to current debates about Restatements of statutory law is significant, since it highlights not just the existence of the previously described substantive and stylistic mismatch between the two, but also offers restatement projects a roadmap for how to resolve them.

When approving the Restatement of Business Associations a few months after the ALI's formation and directing the preparation of tentative drafts, the ALI Council directed ALI Director William Draper Lewis to prepare a full report on the "[p]racticability" of this Restatement. ${ }^{91}$ Lewis was the ALI's first director, and owing to his subject-matter expertise, he had agreed to serve as the project's Reporter. ${ }^{92}$ What appears to have prompted this request from the Council, in Lewis's own words, "was the fear that 'Business Associations' was a statutory subject, and, as such, incapable of restatement." 93

As Reporter for the project, Lewis had a vested interest in ensuring that the project move forward within the ALI and that the Council's fears be allayed. His report therefore defended restating the law of business associations as both practicable and desirable, despite the abundance of statutes in the field. All the same, in the process of defending the field of business associations from the claim that it was incapable of restatement, his report identified different areas of interaction between Restatements and statutes, including those where a restatement was inadvisable and/or needed significant modification in form and substance. The report provided an overview for how the ALI Restatement initiative needed to engage statutory law going forward. Lewis served as the ALI's Director between 1923 and 1947, and the report therefore likely influenced much of the organization's Restatement efforts

90. Founding Committee Report, supra note 36, at 45.

91. Resolution No. 38, supra note 12, at 40.

92. See Statement by the Council of the American Law Institute to the Carnegie Corporation, 1 A.L.I. PROC. 49, 69 (1923).

93. Lewis Report, supra note 13, at 285-86. For an elaboration on this fear, see Minutes of the Second Annual Meeting Held at Washington, D.C.-February 23, 1924, 2 A.L.I. Proc. 5, 68. 
during his leadership. ${ }^{94}$ Indeed, in writing his obituary one prominent friend of his noted that he could not "think of any institution other than the [American Law] Institute which was to so large an extent the expression of the personality of one man." The Lewis Report should be understood against this backdrop.

\section{Types of Statutory Law}

Part IV of the Lewis Report contains the analytical groundwork for the Report's nearly one hundred-page exploration. ${ }^{96}$ Recognizing the ubiquity of statutes in the American legal landscape, the Report identifies four categories of law that relate to and emanate from statutes, which it characterizes as "legal principles." 97 The first is a "statutory principle," which refers to a statement of law expressed in a statute that receives "its sanction as law solely from its expression by a legislative agency." 98 This category appears to refer to rules embodied in a statute that have no prelegislative background in the common law and instead derive their force from the institutional authority of the legislature as primary lawmaker; in other words, from fiat. Particularly telling in Lewis's definition is the subtly pejorative framing of the rule's power as emanating "solely" from institutional status, leaving little room for the identification of reason as a basis for its authority. ${ }^{99}$

The second category is an "interpretative principle," which refers to a principle expressed by an institution other than the legislature that seeks to explain "the meaning of a statutory principle." ${ }^{100}$ Interpretative principles thus refer to principles produced primarily by courts when applying statutory law, through their exposition and extension of the statutory language. It is worth noting that Lewis's identification of interpretation as generating law (i.e., principles) is prescient on its own, since statutory interpretation as a field had yet to take on a firm footing in the academy and the plain meaning approach towards statutes dominated the landscape. The idea that judicial interpretation of statutory text could generate law was well ahead of its time.

The third category was a "common law principle," representing a rule not finding expression in a statute and therefore receiving its authority "solely from its expression either by courts or by learned legal writers." 101 This category was to encompass common law rules - the embodiment of reason and the real source of law as understood at the time.

The final category that Lewis identified is that of a "common law-statutory principle," representing a rule that originates in the common law but is "also expressed" in a statute. ${ }^{102}$ To Lewis, the mere presence of the statute embodying the rule added nothing to its substantive significance and authority. In his view, even if

\footnotetext{
94. The Story of the ALI, supra note 1.

95. George Wharton Pepper, William Draper Lewis, 98 U. PA. L. REV. 4,7 (1949).

96. Lewis Report, supra note 13, at 349-66.

97. Id. at 352 .

98. Id.

99. Id.

100. Id. at 353 .

101. Id. at 352 .

102. Id.
} 
"the statute should be repealed, the principle, not receiving its sanction as law solely from legislative action, would remain law." 103 The central question-which of course Lewis did not expressly address - was whether such statutory inclusion of the rule altered its status vis-à-vis courts. A close reading suggests that he did not see a difference. His discussion of "repeal" and the statement that the rule would subsist even without the statute suggests a belief that the statute added nothing as such. Further, Lewis went on to clarify that he was limiting the idea of an interpretative principle to judge-made rules developed to interpret and expound on statutory text, when such text was of a purely statutory origin, i.e., not itself codifying a common law rule. This clarification therefore implied that courts applying statutory provisions premised on common law rules were expounding the underlying (common law) principle rather than interpreting the statute as such. ${ }^{104}$ In other words, it is fair to read the Report as treating common law-statutory principles as representing provisions today characterized as "common law statutes."

The Report then used this four-fold categorization of statutory rules to develop a further taxonomy of legal subjects, based on the presence and role of statutory texts therein. Here, Lewis identified six categories of subjects based on their mix of statutory and common law, and further whether the statutory law was uniform or non-uniform. ${ }^{105}$ Uniform statutory law represented situations where the entire area of law in the United States was governed by a uniform statutory regime. This could include an area covered by a federal statute (e.g., Pure Food and Drug Act), or a domain covered by a uniform statute that all (or a substantial number) of states had enacted into law (e.g., negotiable instruments). ${ }^{106}$ This was in contrast to subjects governed by non-uniform statutory law (where each state had a different statutory law), subjects where there existed only partly uniform statutory law, and others comprised either wholly of common law or a mix of common law with either uniform or non-uniform statutory law.

Lewis's goal in setting forth the taxonomy was to situate the law of business associations within the American legal landscape, which provided a foundation for his argument that business associations was an area covered either wholly by common law, or by a mix of common law and uniform statutory law-either of which made it suitable for restatement. Yet, in developing the taxonomy, he went on to articulate a general set of rules for the Restatements of Law, on when (and how) a statutory subject was worthy and fit for restatement.

\section{Rules for Restating Statutory Law}

From the taxonomy, Lewis proceeded to develop a set of rules for Restatements of Law in their engagement with statutory subjects. While most of his rules are not relevant to the present discussion, the Report's engagement with uniform statutory subjects is pertinent. Copyright law-being governed today by a comprehensive

103. Id

104. Id. at 352-53.

105. Id. at 354 .

106. See id. 
federal statute-would clearly qualify as a domain of uniform statutory law, as understood and defined in the Report.

The first rule of the framework pertained to subjects governed by uniform statutory law, and while Lewis advocated for their Restatement, he was also clear that the Restatement had to recognize and acknowledge the primacy of the statutory provision. On this the Report was categorical: The statutory provision had to be set forth in the Restatement as the operative rule, which the Report took to be an "obvious" proposition. ${ }^{107}$ Indeed, the Lewis Report went one step further and suggested that the statutory provision be highlighted as the "Principle of Law or Comment" for the issue being restated — what is today referred to in the ALI Restatements as the "black letter text." 108

Of course, mere recitation of the statutory provision would not exhaust the Restatement's engagement with the subject. Lewis added that the "real value of the Restatement would consist in the clarification of the interpretative principles"109_ an elaboration and collection of judicial and executive efforts to understand, expound on, and elaborate the statutory provisions. Lewis therefore saw areas of uniform statutory law as capable of restatement if they reoriented themselves to focus on the centrality of statutory text and relegated other sources to the domain of interpretative principles. The text of the statute had to form the focal point of the Restatement, a proposition that he was unequivocal about.

Lewis then proceeded to focus on the law of business associations, which he defended as a common law subject, if at times consisting of a combination of common law and uniform statutory law (for which he developed additional rules). Upon receiving his report, the ALI Council endorsed further work on the Restatement of the Law of Business Associations, ${ }^{110}$ which went through a few more drafts before being terminated for reasons that were never fully explicated. At least part of the reason one might surmise, given the Council's prior "fear," may have been the cumbersome statutory nature of the field.

The early saga of the Lewis Report serves to highlight just how much of a mismatch between Restatements and statutory law existed in the ALI's conception of its enterprise. Much to his credit, Lewis sought to reduce the mismatch by advancing the idea that the Restatements themselves needed to be adaptable - in both form and substance - for them to overcome the mismatch. And despite his

107. Id. at 358 ("[T] $]$ he Restatement, if it deals with the subject [covered by Uniform Statutory Law] at all, must set forth the statutory provisions as Principles of Law or Comment.").

108. Id. Principles of Law represented "direct statement[s] of law" while Comments contained "either ... direct statements of law, or of reasons for the statements of law made in the Principle or Comment, the reasons being stated in a non-argumentative manner." Id. While Lewis recognized some flexibility as between the two, he nevertheless was unequivocal that the provisions had to be "set forth," an obvious allusion to their verbatim reproduction. $I d$.

109. Id.

110. Resolution No. 168, in Minutes of the Eleventh Meeting of the Executive Committee of the Council-November 15, 1924, 2 A.L.I. PROC. 222, 231 (1924). 
immediate focus, he chose to develop a general framework for the restatement of all forms of statutory law, which led him to formulate a rule for areas governed by a uniform federal statute. The Lewis Report was produced before the ALI embarked on its model code initiatives. When these alternative vehicles of statutory engagement emerged, the lessons of the Lewis Report for uniform statutory domains fell by the wayside, since they were no longer needed; the ALI had found a better avenue for statutory engagement, thereby fencing off the Restatements from the problems that Lewis meticulously identified. And ever since, the ALI has seen little need to revisit the format and style of its Restatements for statutory areas of law for one reason above all others: It simply stayed away from restating statutory subjects. As discussed in the following Section, when it was forced to encounter "scattered" statutes within an otherwise common law domain, ${ }^{111}$ it treated them as common law statutes. All of that changed in 2015, and the simple and sensible modifications to the Restatements advanced in the Lewis Report remain long forgotten.

\section{Restatements ANd Common LaW Statutory Domains}

Recognizing the existence of the basic mismatch, the ALI's Restatements of Law avoided direct engagement with fields dominated by statutes - subjects governed by what the Lewis Report described as "uniform statutory law" where a single federal statute, or identical state statutes, occupied the legal landscape. This did not of course mean that Restatements shied away from any engagement with statutes. That was indeed never their intent, nor was it something that the ALI's founders or the Lewis Report advocated. The Restatements of Law instead only ever engaged statutes when they were "scattered" within broader common law subjects, ${ }^{112}$ thus constituting only a part of the field, with the rest left to the common law or when those statutes themselves embodied common law rules and principles: what Lewis described as statutes made up of "common law-statutory principle[s]."113

As the Lewis Report noted, the Restatements of Law had few problems engaging common law statutory principles, because they treated the operational rules of significance to be the common law rules rather than the statute. ${ }^{114}$ And indeed, this has been how the ALI's various Restatement projects have engaged common law statutory provisions over the years. Since these provisions are seen and treated by courts as being active delegations of lawmaking power to the judiciary, ${ }^{115}$ the

111. See Founding Committee Report, supra note 36, at 20.

112. Founding Committee Report, supra note 36, at 20. Indeed, the Restatements' interaction with such scattered statutes has grown over the years but has remained qualitatively the same since the area/subject being restated has always remained common law, and principally state law at that. See Charles Alan Wright, The President's Letter, 20 A.L.I. REP. 1, 3 (Spring 1998) (detailing the ALI's increased engagement with such statutes).

113. Lewis Report, supra note 13, at 352.

114. Id. at 353. Obviously, Lewis saw there to be no problems with Restatements engaging statutes that were scattered and intermittent within broader common law fields, such as business associations. See $i d$. at 361-62.

115. See generally Margaret H. Lemos, The Other Delegate: Judicially Administered Statutes and the Nondelegation Doctrine, 81 S. CAL. L. REV. 405 (2008). 
Restatements of Law fit the rules that courts develop-albeit under the delegation of the statute-for common law rules, and are thus viewed as being worthy of restatement through clear statements of principle.

In recent debates, defenders of the ALI's Restatement efforts in new legal areas have tried to argue that the reality of the Restatements' engagement with common law statutes (and statutory provisions) reveals the absence of a fundamental mismatch between them and statutes. ${ }^{116}$ Consequently, the form and style of the Restatements of Law, they claim, allow for a seamless extension to the task of restating any statutory subject, including those governed by uniform federal statutes. Even a cursory reading of the Lewis Report, and its effort to distinguish between statutory principles and common law statutory principles, proves the fallacy of this position. Indeed, an honest examination of the Restatements' own dealings with statutory provisions shows the claim to be untrue.

Two such examples, both of which are commonly proffered by deniers of the mismatch, are the treatment of the Lanham Act in the Restatement (Third) of Unfair Competition and the coverage of the Federal Sovereign Immunity Act by the Restatement (Fourth) of Foreign Relations Law. Neither of these Restatement efforts directly engages the statute in its coverage, and for good reason: The statute at issue does not require such engagement, owing to its particular role within the field.

\section{Trademark Law}

A good part of the Restatement (Third) of Unfair Competition is devoted to restating the law of trademarks. ${ }^{117}$ In 1946, Congress passed the Lanham Act, which governs trademark law and unfair competition at the federal level. ${ }^{118}$ The Lanham Act was by all accounts a piece of common law legislation. As the Restatement itself notes, it was "declarative of existing law, incorporating the principal features of common law trademark protection." 119 The Lanham Act therefore consciously allowed individual states to enact their own trademark statutes, and additionally did not preempt common law trademark protection even at the federal level. ${ }^{120}$

This declaratory nature of the statute echoed precisely what the ALI's founders saw as permissible for the Restatements of Law to engage statutes, since the "real" source of the law was the common law. Indeed, the introductory language to the discussion of trademark law in the Restatement voices this sentiment when it notes that the rules relating to trademark law "are applicable to both common law and statutory actions." 121 In other words, the Restatement was not attempting to restate the provisions and jurisprudence emerging from the Lanham Act, but instead a conjoint body of rules generally applicable across statutory and common laws. This

116. See Revesz, Federal Statutes, supra note 33, at 3.

117. RESTATEMENT (THIRD) OF UNFAIR COMPETITION $\S \S 9-37$ (AM. LAW INST. 1995).

118. Lanham Act, Pub. L. No. 79-489, 60 Stat. 427 (1946).

119. RESTATEMENT (THIRD) OF UNFAIR COMPETITION, supra note $117, \S 9 \mathrm{cmt}$. e.

120. Id.

121. Id. ch. 3, intro. note ("The statutory protection of trademarks is largely a codification of the common law, and except as otherwise noted the rules stated in this Chapter are applicable to both common law and statutory actions."). 
approach is apparent in the very manner in which the Restatement approaches trademark doctrine, where it does not limit itself to the statute but instead generates a set of principles drawn from the working of the law more generally. ${ }^{122}$ The restating of the Lanham Act was thus in the category of "common law-statutory principles," to use the terminology of the Lewis Report. ${ }^{123}$

\section{Foreign Sovereign Immunity Law}

Foreign sovereign immunity law, found in portions of the Restatement on Foreign Relations Law, is a little more complicated. The area of foreign sovereign immunity law is a domain that is largely common law in origin. ${ }^{124}$ In 1976, Congress codified a part of the domain by enacting the Federal Sovereign Immunity Act (FSIA), making clear that it intended to codify a doctrine that had been recognized previously at common law and in international law. ${ }^{125}$ All the same, what became unambiguously clear is that the FSIA was only ever intended to cover a part of the territory of federal sovereign immunity. ${ }^{126}$ The common law was to subsist as a set of principles surrounding the FSIA. And in a landmark decision on the FSIA, the Supreme Court adopted a narrow reading of the FSIA, rendering it altogether inapplicable to the immunity of individual (as opposed to state) defendants. ${ }^{127}$ Individual immunity - as with other doctrines - was to be governed by the common law of foreign sovereign immunity. Unlike the Lanham Act, then, the FSIA did not codify all of the prior common law in the domain. Instead, it codified a portion of the prior common law so as to eliminate inconsistencies and left the majority of the field to the common law. ${ }^{128}$

The FSIA is to be contrasted with a uniform statute that purports to occupy an entire subject area. In codifying prior case law and then limiting itself in a significant way, the statute cannot be said to "govern" the field of federal sovereign immunity, which continues to depend in large measure on the uncodified and statutorilyuntouched domain of common law. This reality makes it relatively unproblematic for incorporation into a broader Restatement of the topic of sovereign immunity, which would thus need to focus on both sources in order to be accurate and comprehensive.

122. Id. § $9 \mathrm{cmt} . \mathrm{f}$ (dealing with the definition of "trademark")

123. Lewis Report, supra note 13, at 352.

124. See Curtis A. Bradley \& Laurence R. Helfer, International Law and the U.S. Common Law of Foreign Official Immunity, 2010 SUP. CT. REV. 213, 216-21 (2010).

125. Foreign Sovereign Immunities Act (FSIA), Pub. L. No. 94-583, 90 Stat. 2891 (1976).

126. See Samantar v. Yousuf, 560 U.S. 305 (2010) (holding that the FSIA only applied to federal state immunity and not individual immunity); Permanent Mission of India v. City of N.Y., 551 U.S. 193 (2007).

127. Samantar, 560 U.S. at 305.

128. See Ingrid Wuerth, The Future of the Federal Common Law of Foreign Relations, 106 Geo. L.J. 1825, 1834 (2018) ("The scope of the federal common law of foreign relations has contracted in most areas over the past few decades, but immunity-related issues are an exception.... The Court [in Samantar] expanded the scope of federal common law governing immunity."). 


\section{The Continuing Mismatch: A CONCEIT OF "Voice" AND "INTERPRETATION"}

As we have seen, the mismatch between Restatements of Law and statutory subject areas was driven by a conception of law and lawmaking with which the ALI's founders imbued the Restatement enterprise. This included a belief in the virtues of judge-made law as embodying reason, and in the simultaneous inferiority of legislation as a credible source of law, principles, and policy. Much of this conception has of course changed in the many decades since, especially given the extensive proliferation of federal statutes. And yet, the Restatements have done nothing to adapt themselves to the changing landscape, either in form or substance. The mismatch thus continues to endure, and what has enabled it to do so, first starting a few decades ago, has been a fundamental feature of the Restatements of Law that is implicit in its structure and orientation, namely, its voice.

Much of the early criticism leveled against the first round of Restatements centered around their seeming adherence to the ideals of Legal Formalism, which prized the logical coherence and autonomy of legal doctrine and principles of law. ${ }^{129}$ The ALI's response to this criticism was that it was merely attempting to distill the law as it was (or is) at a particular point in time, in an effort to remain faithful to its goal of clarification and simplification. ${ }^{130}$ As Legal Realism took hold of the U.S. legal academy in the second quarter of the twentieth century, the ALI became increasingly aware of the precariousness of its position, which seemed to abjure the ideal of reforming the law, in favor of preserving it as is. ${ }^{131}$ This prompted the ALIthen under the directorship of Herbert Wechsler - to take the position that the Restatements of Law were meant to be more than just purely descriptive, but instead embodied clear normative content. ${ }^{132}$ Yet if they were purely prescriptive, they would of course fail to be seen as "restating" the law in any sense of the term. Wechsler's approach was to blend the is-ought distinction through the method of the common law, ${ }^{133}$ noting that Restatements "should ... give weight to all of the considerations that the courts, under a proper view of the judicial function, deem it right to weigh in theirs." 134

129. See, e.g., Charles E. Clark, The Restatement of the Law of Contracts, 42 YALE L.J. 643 (1933); Thurman Arnold, The Restatement of the Law of Trusts, 31 CoLUM. L. REV. 800 (1931); Hessel Yntema, The Restatement of the Law of Conflicts, 36 CoLUM. L. REV. 183 (1936); Arthur L. Goodhart, Restatement of the Law of Torts, 83 U. PA. L. REV. 411 (1935); Leon Green, The Torts Restatement, 29 ILL. L. REV. $582(1935)$.

130. See, e.g., Herbert F. Goodrich, Institute Bards and Yale Reviewers, 84 U. PA. L. REV. 449 (1936). Goodrich served as the ALI's Director right after Lewis, from 1947 to 1962.

131. For a pointed reference to the ALI's old position, see Clark, supra note 129, at 650 (noting how the Restatement plan imposed on itself the "important limitation that the now law must be stated").

132. See Herbert Wechsler, Report of the Director, The American Law Institute, 44 A.L.I. ANN. ReP. 5, 5 (1967) [hereinafter Wechsler Report]. The ALI adopted Wechsler's position as their own in 1968; see also Richard L. Revesz, The Debate Over the Role of Restatements, 41 A.L.I. REP. 1 (Summer 2019).

133. For a fuller elaboration, see Herbert Wechsler, Restatements and Legal Change: Problems of Policy in the Restatement Work of the American Law Institute, 13 ST. LOUIS U. L.J. 185, 190 (1968) (observing that it is impossible to differentiate "what courts will do" from the question of "what they ought to do").

134. Wechsler Report, supra note 132, at 5. 
Wechsler's framing, while understated, nevertheless had profound implications. It put the Reporters of the Restatements in the position of judges deciding common law cases. Judges - unlike academics, or treatise writers - are participants in the common law process of lawmaking rather than mere bystanders or observers. And as such, they operate under the constraints and liberties that attach to the institution of courts as lawmakers. ${ }^{135}$ One such feature in the common law, which Wechsler's framing allowed the Restatements to adopt, was therefore the declaratory theory of the common law, under which a common law court neither states nor makes the law, but through the process of discovery merely "declares" it. ${ }^{136}$ The ALI Council endorsed this position in its next set of Restatements. ${ }^{137}$

By the year 2005, the ALI decided that this "voice" was sufficiently representative of its Restatement initiative that it memorialized it in a formal guidance document to all new project Reporters, wherein it categorically declared:

\begin{abstract}
Although Restatements are expected to aspire toward the precision of statutory language, they are also intended to reflect the flexibility and capacity for development and growth of the common law. They are therefore phrased not in the mandatory terms of a statute, but in the descriptive terms of a judge announcing the law to be applied in a given case. ... A Restatement thus assumes the perspective of a common-law court, attentive to and respectful of precedent, but not bound by precedent that is inappropriate or inconsistent with the law as a whole. ${ }^{138}$
\end{abstract}

This characterization vividly highlights the is-ought merger that underlies the process through which the common law evolves judicially. And the ALI deserves full credit for spelling it out so directly.

Enter the world of statutes. The perspective of a common law judge is fundamentally different from that of a judge engaged in the enterprise of statutory interpretation. The distinction is neither subtle nor new; it is a reality of the American legal system that scholars and courts (including the Supreme Court) have recognized. ${ }^{139}$ The distinction derives from the idea that in statutory domains courts are "faithful agents" of the legislature. ${ }^{140}$ This in turn implies that they should accord heightened deference to the directives of the enacting body generating the

135. The most exhaustive and illuminating account of this process was by Justice Cardozo. See generally BENJAMIN N. CARDOZO, THE NATURE OF THE JUDICIAL PROCESS (1921).

136. See, e.g., Allan Beever, The Declaratory Theory of Law, 33 OXford J. Legal Stud. 421 (2013); Brian Zamulinski, Rehabilitating the Declaratory Theory of the Common Law, 2 J.L. \& CTS. 171 (2014); John W. Salmond, The Theory of Judicial Precedents, 16 LAW Q. REV. 376 (1900); Stephen E. Sachs, Finding Law, 107 CALIF. L. REV. 527 (2019).

137. See White, supra note 11, at 46-47.

138. ALI, CAPTURING THE VOICE (2005), supra note 5, at 5 (emphasis added).

139. See Robert Keeton, Venturing To Do Justice 79-80 (1967); Edward Levi, An Introduction To Legal Reasoning, 15 U. CHI. L. REV. 501, 540 (1948); William N. Eskridge, Jr., Overruling Statutory Precedents, 76 GEO. L.J. 1361, 1363 (1988). For an account of the Supreme Court's position, see Lawrence C. Marshall, "Let Congress Do It": The Case for an Absolute Rule of Statutory Stare Decisis, 88 Mich. L. ReV. 177 (1989).

140. See Amy Coney Barrett, Substantive Canons and Faithful Agency, 90 B.U.L. REV. 109, 112 (2010) (describing the idea and noting how it represents the "conventional view") [hereinafter Barrett, Substantive Canons]; Thomas W. Merrill, Legitimate Interpretation-Or Legitimate Adjudication?, 105 CORNELL L. REV. 1395, 1420 (2020). 
"authoritative text" in pursuit of the basic idea of popular sovereignty. ${ }^{141}$ The faithful agent idea is widely accepted in U.S. legal thinking, ${ }^{142}$ and at its core functions to recognize that, unlike in the common law setting where courts are declaring law, in statutory domains their primary function is adjudicating the dispute by applying preexisting law.

The distinction manifests itself in important ways in judicial practice and reasoning. For instance, when a judge is deciding a case in the context of a statute (rather than as a common law judge), it is a very well-established proposition that the constraint of stare decisis is, at least in theory, especially strong. ${ }^{143}$ Precedents emerging from previous interpretations of the statute-known as "statutory precedents"- are given significantly more weight than are common law precedents produced by judges in the declaratory exercise of their lawmaking function. ${ }^{144}$ They cannot be overruled willy-nilly in the pursuit of a better position, or an improvement, in the same way in which the common law grows. ${ }^{145}$ Indeed, the uniqueness of statutory precedents is today accepted as a reality by the Supreme Court regardless of the type of statute involved, and has even been extended to "judicially created doctrines" that seek to implement a statute but are entirely court-made. ${ }^{146}$

Even if one disagrees with the value of a strong presumption against overruling statutory precedents, ${ }^{147}$ at the very least what this means is that a court engaged in synthesizing statutory precedents and the text of a statute into a single narrative is forced to adopt a different "voice" from the one that it would otherwise adopt in a common law setting. And while the eventual outcomes in both situations may be the same, the process of reasoning that a court is forced to adopt for one will be qualitatively different. ${ }^{148}$

141. Merrill, supra note 140, at 1420.

142. See JOHN F. MANNING \& MATTHEW C. STEPHENSON, LEgiSLATION AND REgUlation: CASES AND MATERIALS 24 (3d ed. 2017) (noting how the prevailing theories of interpretation are all grounded in the idea of legislative supremacy, which adheres to the idea of faithful agency); Merrill, supra note 140, at 1421 (noting the "very broad consensus" in the U.S. system about the idea); Barrett, Substantive Canons, supra note 140, at 112 (describing it as "conventional").

143. Marshall, supra note 139, at 181-82.

144. Id. For an account defending it in relation to non-Supreme Court precedents, see Amy Coney Barrett, Statutory Stare Decisis in the Court of Appeals, 73 GEO. WASH. L. REV. 317 (2005) [hereinafter Barrett, Statutory Stare Decisis].

145. Scholars have debated the amount of flexibility that courts have under this rule. Eskridge argues that courts should have more freedom based on "changed circumstances" that render the prior precedent inconsistent with legislative expectations and "evolving statutory policy." Eskridge, supra note 139, at 1363-64. Marshall argues that the position should be more absolute. Marshall, supra note 139.

146. Kimble v. Marvel Ent., LLC, 576 U.S. 446, 456 (2015) (“"[W]e apply statutory stare decisis even when a decision has announced a 'judicially created doctrine' designed to implement a federal statute.").

147. The argument that legislatures can always overturn erroneous judicial interpretations overlooks the often enormous challenge of statutory reform. Congress is a very busy institution, sometimes making even clear errors or oversights difficult to correct.

148. Even Eskridge, who as a normative position argues in favor of abandoning the rule, acknowledges this reality, suggesting an engagement with the statute and its goals:

Under the evolutive approach suggested by the Court's common law decisions, the Court would overrule a statutory precedent when the reasoning underlying the precedent has been discredited 
Thus, while a Restatement could adopt the perspective of a common law court in common law domains, that perspective is fundamentally mismatched and ill-suited to a statutory subject where the court is engaged in the enterprise of interpretation. When a court chooses to alter a common law precedent, it can either expressly overrule the precedent or instead engage in the fiction of declaring the law as it always has been without expressly overruling the prior precedent. For the most part, common law courts choose the latter, which is what Wechsler favored for the Restatements. With statutory precedents, a court usually readily admits that it is overruling a statutory precedent, and offers an explanation for this consistent with the statute. Its voice is therefore fundamentally different when engaged in the task of statutory interpretation - for reasons having to do with the institutional structure of lawmaking. ${ }^{149}$

This does not in any way suggest that courts involved in statutory interpretation are either committing themselves to textualism, or indeed not making law. To the contrary, as most scholars would acknowledge, interpretation is lawmaking. Yet, it is different in form and emphasis from the process of common law development. Fidelity to the statute, its background, and legislative intent form the overarching anchors of the narrative, and they constrain the judicial role in important ways. Of course, to the extent that a statute is a common law statute that delegated lawmaking back to courts through open-ended language, courts may blend common law and statutory engagement into a unified process. ${ }^{150}$ But such provisions are the exception rather than the rule. To convert all instances of statutory interpretation into instances of statutory common law-making would be to deny the uniqueness of the judicial role in statutory interpretation.

The accepted voice (and perspective) of the Restatements of Law therefore simply does not fit the challenge of parsing legislative materials and engaging statutory precedents. In 2015, when it was on the cusp of embarking on its first ever restatement of a statutory subject, the ALI revisited its position on "voice." Rather than update it, it simply reaffirmed its age-old logic and adhered to the unidimensional position that the Restatement should adopt the position of a "common-law court." I51 In so doing, it brought the mismatch forward into the current era. In the next Part, we turn to the Restatement of Copyright, where the mismatch has been glaringly highlighted.

over time; the precedent's consequences are positively troublesome, unfair, or contrary to current statutory policies; and practical experience suggests that the statutory goals are better met by a new rule that does not unduly undermine the reliance interests of Congress and private persons who reasonably acted upon the basis of the old rule.

Eskridge, supra note 139, at 1392.

149. Barrett examines the competing theories used to justify the doctrine. See Barrett, Statutory Stare Decisis, supra note 144, at 322-30.

150. Eskridge, supra note 139, at 1377

151. AM. L. INST., CAPTURING THE VOICE OF THE AMERICAN LAW INSTITUTE: A HANDBOOK FOR ALI REPORTERS AND THOSE WHO REVIEW THEIR WORK 5 (rev. ed. 2015) [hereinafter ALI, CAPTURING THE VOICE (2015)]. 


\section{RESTATING THE STATUTORY LAW OF COPYRIGHT}

Notwithstanding the arguable contradiction and evident challenges of "restating" statutory law, the American Law Institute launched the Copyright Restatement Project in 2014 without apparent recognition that it was entering dangerous waters. Earlier that year, the ALI brought on a new director whose scholarly career focused on environmental law, a field of law grounded in statutory and administrative law. He viewed statutory Restatements as the ALI's next frontier. Neither the Council, Director, nor reporters appeared to be aware of the warnings that had foreshadowed the ALI's efforts to restate statutory domains, nor indeed the lessons learned from those failed and abandoned efforts.

Copyright law may have seemed like a good candidate for such an experiment. ${ }^{152}$ U.S. copyright law has a rich common law pedigree. Nonetheless, the Copyright Act of 1976, which largely supplanted prior enactments and almost entirely preempted state common law, ${ }^{153}$ is one of the most detailed and complex federal statutes. The 1976 Act vastly increased the role of governmental agencies - the Copyright Office, the Librarian of Congress, and Copyright Royalty Tribunals - in the administration of copyright law. ${ }^{154}$ Numerous subsequent enactments further expanded the girth, complexity, and regulatory dimensions of the federal copyright regime.

The ALI initially indicated that the Copyright Restatement Project would focus on common law features, but soon expanded its focus toward comprehensive restating of the copyright regime. The Reporters took the common law Restatement template and started to rewrite statutory text as "black letter law." The project was soon mired in the same political wrangling that has long dogged copyright reform. ${ }^{155}$

As advisers to the project who were sympathetic to the ALI's foray into the domain of statutory subjects, the authors of this Article strongly urged the leadership of the project as well as the ALI Council to do the additional groundwork needed to develop a successful Restatement of statutory law. Central to such groundwork was the development of a sound methodology for Restatements of Law that takes statutory interpretation into consideration. The field of statutory interpretation has evolved tremendously in the many decades since the ALI embarked on its Restatements.

This Part examines the ALI's failure to take these concerns seriously and illustrates its consequences. In focusing on the question of methodology, we are of course acutely aware that there are other elements of equal (and perhaps greater)

152. Other factors may have influenced the choice of copyright law as well.

153. See 17 U.S.C. $\$ 301$. Due to the long duration of copyright protection, some vestiges of the 1909 Act remain. For example, courts still look to 1909 Act legislation and jurisprudence in assessing copyright subsistence and ownership with regard to works created prior to January 1, 1978, the effective date of the 1976 Act.

154. Liu, supra note 23, at 105-14.

155. See Letter from Sarang V. Damle, U.S. Copyright Off. Gen. Couns., et al., to ALI Dir. Richard L. Revesz et al., Re: Preliminary Draft No. 2 (Nov. 9, 2016); Letter from Jacqueline Charlesworth, U.S. Copyright Off. Gen. Couns., to ALI Dir. Richard L. Revesz et al., Re: Preliminary Draft No. 1 (Dec. 1, 2015); Glenn G. Lammi, Will the American Law Institute "Restate" or Try To Rewrite U.S. Copyright Law?, FORBES (Apr. 28, 2015), https://perma.cc/PL7V-MFLL. 
significance to the success of such an effort, which we are exploring in an ongoing project. Part II.A summarizes the origins of the Copyright Restatement Project, tracing how the ALI hastily shifted a Principles project proposal to a Restatement initiative. Part II.B chronicles the methodological controversy and confusion that has plagued the actual working of the project, using the example of a statutory provision crafted during the analog age that has gained salience in the digital age.

\section{A. Origins: From Principles To Restatement}

The Copyright Restatement Project traces back to Professor Pamela Samuelson's efforts to reform copyright law and gain the ALI's support in pursuing a copyright project. In 2007, Professor Samuelson invited and convened twenty law professors, copyright law practitioners, in-house lawyers at technology and entertainment firms, and a former ALI President to participate in the "Copyright Principles Project" ("CPP"). ${ }^{156}$ The CPP aimed to explore "how current copyright law could be improved and how the law's current problems be mitigated." 157 The group met three times annually over the next several years. Professor Samuelson led the drafting of the CPP Report which set forth guiding principles, assessed the consistency of those principles with copyright law, and presented twenty-five copyright reform "recommendations." 158 The CPP Report was designed to be reformative.

In a 2013 book review, Samuelson declared that " $[\mathrm{t}]$ he most promising way to work toward more comprehensive copyright reform would be for the American Law Institute (ALI) to articulate principles for a well-balanced and public-spirited copyright regime."159 In a September 2013 letter to then-ALI Director Lance Liebman, Professor Samuelson advocated that the ALI launch a Copyright Principles Project. ${ }^{160}$ Her letter held out the CPP as a model and offered to assist the ALI with fundraising and identification of reporters and advisers. Crucially, her proposal called for a "Principles" project, an idea warranting elaboration given its role in the evolution of the ALI.

156. See Pamela Samuelson et al., The Copyright Principles Project: Directions for Reform, 25 BERKELEY TECH. L.J. 1175, 1180 (2010) [hereinafter CPP Report] (listing CPP participants).

157. Id. at 1176 .

158. Notwithstanding the CPP's presentation of reform recommendations, it notes that "we do not intend affirmative statements or the use of phrases, such as 'we recommend' or 'we believe,' to suggest that the group as a whole was uniformly in support of each particular view stated," CPP Report, supra note 156, at 1197-98, and that "various members of the group maintain reservations and even objections to some proposals described as recommendations," id. at 1179. Jon Baumgarten, former Copyright Office General Counsel and retired copyright law practitioner who participated in the CPP, testified that the CPP did not generate "overwhelming or even a good deal of substantive agreement," but rather was "more attentive to perceived problems caused by copyright to access and related interests of 'users' than to the substantive and remedial/enforcement needs of 'copyright owners' in the Twenty First Century." See A Case Study for Consensus Building: The Copyright Principles Project: Hearing Before the Subcomm. on Cts., Intell. Prop., \& the Internet of the H. Comm. on the Judiciary, 113th Cong. 12-13 (2013).

159. See Pamela Samuelson, Is Copyright Reform Possible? A Critical Evaluation of Two Major Contributions To the Copyright Literature, 126 HARV. L. REV. 740, 743, 770-78 (2013).

160. Letter from Professor Pamela Samuelson to ALI Dir. Lance Liebman, Proposal for an American Law Institute Principles of Copyright Project (Sept. 12, 2013), https://perma.cc/2HXX-NTAE. 
The Principles project was an innovation that the ALI introduced in 1984 when one of its very controversial efforts, the Corporate Governance Project, was met with significant resistance during its early days. ${ }^{161}$ While the project began as a Restatement initiative, it soon attracted criticism for being overtly reformative, a premise that it did not hide. ${ }^{162}$ Faced with this criticism, then-ALI Director Wechsler decided to drop the name "Restatement" from the project and instead articulate a set of principles for the field, even if they did not seek to restate existing law. ${ }^{163}$ Thus emerged the ALI's Principles projects, which have proliferated in the years since. By 2005, they had assumed a fairly stable formulation such that the ALI defined them as projects that "assume the stance of expressing the law as it should be, which may or may not reflect the law as it is."164 What this connoted was clearly a hybrid structure, wherein Principles initiatives were not necessarily reformative and might indeed restate existing law, yet they were not limited to that mission. To avoid any ambiguity, the ALI further insisted that the "commentary make clear the extent to which the black-letter principles correspond to actual law," 165 thereby seemingly eschewing the declaratory (i.e., common law) court stance embodied in Restatements. Samuelson's proposal was therefore directed at having the ALI put copyright law through this hybrid structure, which would have required accounts of the existing law and the aspirational direction for the subject to be kept separate.

Liebman was near the end of his directorship term and did not take action on Samuelson's proposal. Nonetheless, in passing the Director baton to Revesz, Liebman highlighted the central question of whether the ALI was correct to distinguish between Restatement and Principles projects and advised against taking up projects that could "descend[] into political dustups." 166

As Revesz was taking the helm in 2014, his NYU colleague, Professor Christopher Sprigman, pitched a Copyright Restatement project. ${ }^{167}$ His proposal highlighted the political tensions surrounding copyright law and proposed the use of a Restatement project to address the ills that Congress is unlikely to address any time soon. ${ }^{168}$ Recognizing that Restatements were directed at courts, Sprigman emphasized that "it falls to the federal courts to attempt to improve the fit between a mid-20th century copyright law and 21st century digital technologies," and as justification for this he further observed that "the current copyright law is open-texted

161. See Ali, Capturing the Voice (2015), supra note 151, at 15. For an overview of the Project and its accompanying controversy, see Jonathan R. Macey, The Transformation of the American Law Institute, 61 GEO. WASH. L. REV. 1212 (1993).

162. For an overview, see Macey, supra note 161, at 1216; Alex Elson \& Michael L. Shakman, The ALI Principles of Corporate Governance: A Tainted Process and a Flawed Product, 49 BUS. LAW. 1761, 1763 (1994).

163. PRINCIPLES OF THE LAW, CORPORATE GOVERnANCE: ANALYSIS AND RECOMMENDATIONS, at vii-viii (AM. L. INST., Tentative Draft No. 2, Apr. 13, 1984).

164. ALI, CAPTURING THE VOICE (2005), supra note 5, at 12 (emphasis added).

165. Id.

166. Lance Liebman, My Time as Director and Possible Next Steps for ALI, 36 A.L.I. REP. 1, 2, 17 (Spring 2014).

167. See Memorandum from Chris Sprigman to Ricky Revesz, Proposed ALI Restatement of Copyright Law (Sept. 2, 2014).

168. Id. at 2 . 
enough that its coherence and effectiveness could be advanced significantly via common law development." 169

Very shortly after Sprigman's memorandum was sent, the ALI announced the approval of the project as a Restatement initiative - the "Restatement of the Law, Copyright"-with Sprigman as Reporter. ${ }^{170}$ Revesz acknowledged that the copyright project was "a departure from our typical Restatement, which deals with traditional common law areas. Copyright, of course, is predominantly a statutory area, but it is fitting for a Restatement because of the broad discretion that judges must exercise on key concepts such as the subject matter covered by copyright and the nature of fair use." ${ }^{\prime 11}$ He expressed his hope that the project would be completed by the ALI's 100th anniversary in 2023. ${ }^{172}$

Implicit in the move from Principles project to Restatement was a broader reorientation in the ALI's mission, one that Liebman had warned about in his departing message. And this was the age-old question of whether the ALI's Restatement of Law efforts needed to eschew the idea of being reformative, in order to devote themselves to restating the current law and thus relegating reformative efforts to Principles projects. As noted previously, Wechlser had consciously imbued Restatements with a normative component, which the Council endorsed. The decision to treat the copyright project as a Restatement effort expanded upon this view, which Revesz later reaffirmed. Writing in 2019 about the debate, he reiterated that Wechsler's vision was "the guiding light for the Institute's Restatement work" and made explicit the notion that Restatements were capable of embodying normative provisions, including identifying "pattern[s] developing in the case law" even when not yet a clear rule. The Restatement status of the project was thus reaffirmed, and with it Revesz's expanded conception of the Restatement as an enterprise that blended the positive with the normative. ${ }^{173}$ The move into restating comprehensive statutory regimes via the common law template was a dramatic departure from past practice, raising serious issues of legitimacy.

Somewhat surprisingly though, in all of the early discussion (and debate) about the project and its status as a Restatement initiative, absolutely no mention whatsoever was made of the unique challenges that the statutory nature of the subject might create. Indeed, we should also note that despite all of the initial communications surrounding the Restatement acknowledging the statutory nature of copyright, no thought was given to the possibility that the ALI's efforts in the area of copyright might lie in producing a model federal code. What this highlights again,

169. Id.

170. Four New Projects to Begin in 2015, 37 A.L.I. ReP. 1, 1-2 (Fall/Winter 2014).

171. Richard L. Revesz, Director's Message, in THE AMERICAN LAW INSTITUTE ANNUAL REPORT 2013-2014, at 5 (2014).

172. See id.

173. It is worth noting that contemporaneously, the ALI also updated and modified its understanding of "Principles" projects. Whereas the previous understanding had left the door open to the possibility that such projects "may be addressed to courts" along with other institutions, and thus "may" reflect the existing law while making clear the distinction between is and ought, the new understanding relegated courts to the peripheries of such projects, noting that "they can ... be addressed to courts when an area is so new that there is little established law." ALI, CAPTURING THE VOICE (2015), supra note 151, at 13. 
then, is how the ALI's view of its Restatement enterprise dominated the choice of framework and approach. Questions of form, methodology, and the like were altogether missing, which contributed to doubts about the project.

\section{B. IGNORING AND ENTRENChing THE Mismatch}

The Restatement of the Law of Copyright project took off in earnest in 2015. We joined the project as advisers and have sought to share our knowledge of copyright legislation, common law development, and statutory interpretation. As we chronicle below in Part II.B.1, we were immediately concerned by the project's shoehorning restatements of statutory law into a template developed for common law principles, the full extent of which was described in Part I. Our efforts to bring the first largescale statutory restatement into better alignment with statutory interpretation were almost entirely rebuffed. Part II.B.2 illustrates the results of that rejection, and how it entrenched the fundamental mismatch between Restatements and uniform statutory law even further. Using the example of copyright law's distribution right-a provision that is informed by a rich legislative background - we show how the ALI's failure to address the methodological differences between common law and statutory law can produce incoherent, misleading, and seemingly biased results, which risk undermining the credibility of the entire project.

It bears emphasis that we are by no means suggesting that copyright law would not benefit from modernization, and perhaps indeed from judicially-crafted changes. We are simply making the obvious point that a credible Restatement of statutory law needs to recognize the appropriate role that a statute plays in the overall landscape. It should focus on the best way to aid judges in interpreting that law, which is to provide them with unbiased reporting of the statutory text, and where relevant, the pertinent legislative history.

\section{Ignoring the Mismatch: Putting the Cart Before the Horse}

The Copyright Restatement Project distributed its first draft, covering copyright subject matter and standards, on November 6, 2015. ${ }^{174}$ The draft followed the general template for traditional common law Restatements without any apparent recognition of the different character of a statutory restatement. ${ }^{175}$ It was also clear that the project was not limited to common law aspects of copyright law. This outline included chapters on Subject Matter and Standards, Scope of Protection, Ownership, Duration, Formalities, Rights and Limitations, Infringement, Secondary Liability, Remedies, and Copyright Protection and Management Systems. ${ }^{176}$ The preamble for the draft contained an extended excerpt from the ALI's Revised Style Manual describing the voice and orientation of Restatements of Law. ${ }^{177}$

174. Restatement of the Law, Copyright (Am. L. Inst., Preliminary Draft No. 1, Nov. 6, 2015) [hereinafter Restatement Preliminary Draft No. 1 (2015)].

175. See id.

176. See id. at $17-18$

177. See id. at xi-xii (excerpt from ALI, CAPTURING THE VOICE (2015), supra note 151). 
Many advisers were confounded by the incongruence of restating a detailed federal statutory regime using a framework that was designed for a different purpose. The use of the ALI's usual term for its distilled rule, "black letter law," to restate the epitome of black letter law-federal statutory provisions - by paraphrasing, condensing, and rewording them, was especially jarring and confusing. The lack of attention to the text, legislative history, and administrative context of copyright law implicit in the traditional framework would not aid busy judges in identifying pertinent sources for interpreting statutory provisions. Indeed, it would do just the opposite and produce additional confusion. A new and assertively better "black letter law" drafted not by duly elected legislators but by the ALI, insulated from the rigors of the legislative process, would compete with statutory text and open up spurious lines of advocacy.

Yet, unlike several advisers who saw these defects as requiring the project to be either terminated or reoriented towards a "Principles" framework, we believed that the Restatements of Law were fully capable of being updated and adapted to the meet the needs of statutory interpretation and the domain of a subject with a mixed heritage such as copyright law. Indeed, our hope was that if the project would successfully make these changes, it could serve as a worthwhile model for Restatements of additional federal statutory areas.

We raised these issues at the first adviser and Members Consultative Group (MCG) meetings and were met with pushback from the ALI and project leadership. They offered us three responses. First, that restating statutes was not significantly different from restating common law. Second, that the ALI had previously restated statutes using the same approach as the common law Restatements, citing the Restatement of Unfair Competition, which covers trademark law, and the Restatement of the Foreign Relations Law of the United States, which deals with aspects of the Foreign Sovereign Immunities Act. And third, they noted that the Reporters would address "General Principles," designated as Chapter 1, at the end of the project, and this would address the modification in framework.

The first response revealed a lack of appreciation of legal institutions and judicial decision making, as well as lack of understanding the ALI's experience with "restating" comprehensive statutory regimes. As elaborated in Part I, even the ALI's founders keenly appreciated the imprudence of simplistically applying the original framework of the Restatements to statutory subjects. In the contemporary age, such an effort was seen by legislators, the Copyright Office, and the Patent Office as hubris. ${ }^{178}$ The second response was similarly misplaced. Again, as noted before,

178. See Sen. Thom Tillis, Rep. Harley Rouda, and Rep. Ted Deutch, ALI's Proposed Restatement of Copyrights Has the Potential To Harm the Creative Industries, HILL (Feb. 11, 2020), https://perma.cc/RR25-63WF; Letter from Sen. Thom Tillis, Rep. Ben Cline, Rep. Theodore E. Deutch, Rep. Martha Roby, and Rep. Harley Rouda to ALI Dir. Richard L. Revesz (Dec. 3, 2019), https://perma.cc/UG5U-RPP5 (stating that "laws created through federal statute, including federal copyright law, are ill-suited for treatment in a Restatement because the law is clearly articulated by Congress in both the statute and the legislative history. In creating legislation, Congress develops legislative history through hearing testimony and Committee Reports. Legislation is then expertly interpreted by agencies charged with that authority by Congress - such as the U.S. Copyright Office and 
neither of the projects suggested sought to restate a comprehensive federal statutory regime. ${ }^{179}$ And indeed, the statutory domains restated therein were common law in origin and self-consciously designed against the backdrop of and in interaction with the common law, partaking of what Lewis described as "common law-statutory principles."180 Regarding the third response, if there was ever a case of putting the cart before the horse, the Restatement of Copyright was it.

Prompted by these rumblings, Revesz defended the ALI's decision to restate statutes using the common law model. ${ }^{181}$ While recognizing that prior Restatements did not "for the most part" "provide courts with guidance on how to interpret those statutes," he again cited the more recent and modest efforts to encompass statutory elements in other restatement projects, implying that they provide precedent for pursuing near-comprehensive restatement of a broad federal statute using the same template and approach as common law Restatements. ${ }^{182}$ He then shifted the rationale for statutory restatements to the proposition that what the ALI "seek[s] to do in those areas is to provide guidance to the courts where the scope for judicial discretion is broad, which can be the case even for statutes that are very detailed."183

This rationale, however, in no way captures the profound differences between common law jurisprudence and statutory interpretation. To describe a court's explication of statutory meaning and applicability as paralleling its role in developing the common law under the singular rubric of "discretion" is simply inaccurate. Common law courts have functionally unfettered discretion in developing the law, relying exclusively on precedent and considerations therein. Statutes operate differently. As scholars have noted, "statutes are drafted with different degrees of interpretive discretion in mind" and thus "[t]he level of linguistic generality permits an inference about the speaker's willingness to delegate gap-filling discretion to another person."184 Statutes can incorporate the same level of discretion as the common law when they choose to (i.e., with common law-statutory provisions, or

U.S. Patent and Trademark Office."); Letter from Karyn Temple Claggett, Acting Reg. of Copyrights, to ALI President David Levi et al., Re: Council Draft No. 1, Restatement of the Law, Copyright (Jan. 16, 2018), https://perma.cc/C6QU-6KHU; see also Letter from Regan Smith, U.S. Copyright Off. Gen. Couns. et al., to ALI Dir. Richard L. Revesz et al., Re: Preliminary Draft No. 4 (March 4, 2019); Letter from Regan Smith, U.S. Copyright Off. Gen. Couns. et al., to ALI President David F. Levi et al., Re: Council Draft No. 2, Restatement of the Law, Copyright (Oct. 16, 2018); Letter from Sarang V. Damle, U.S. Copyright Off. Gen. Couns. et al., to ALI Dir. Richard L. Revesz et al., Re: Preliminary Draft No. 3 (Dec. 4, 2017); Letter from Sarang V. Damle, U.S. Copyright Off. Gen. Couns. et al., to ALI Dir. Richard L. Revesz. et al., Re: Preliminary Draft No. 2 (Nov. 9, 2016); Letter from Jacqueline Charlesworth, U.S. Copyright Off. Gen. Couns. to ALI Dir. Richard L. Revesz et al., Re: Preliminary Draft No. 1 (Dec. 1, 2015); Letter from Andrei Iancu, Dir. of the USPTO, to ALI Dir. Richard L. Revesz et al, Re: ALI Restatement of Copyright Law (Oct. 1, 2018); Devlin Hartline, Members of Congress the Latest to Question ALI's Restatement of Copyright, CTR. FOR THE PROTECTION OF INTELl. Prop. (Dec. 5, 2019) https://perma.cc/CTL2-G2ME.

179. See supra Part I.C.1-2.

180. See supra Part I.B.1.

181. See Revesz, Federal Statutes, supra note 33, at 3.

182. See id.

183. See id (emphasis added).

184. William N. Eskridge, Jr. \& Judith N. Levi, Regulatory Variables and Statutory Interpretation, 73 WASH. U. L.Q. 1103, 1111 (1995). 
common law statutes), but they usually do not, since that would defeat the entire purpose of the legislative exercise. The Copyright Act of 1976 certainly did not leave all of copyright law to judicial discretion. Much of the nearly two decades crafting it did precisely the opposite. While interpretive discretion certainly exists within the statute, it is neither uniform nor uniformly broad. And therein lies the challenge.

Revesz devoted the remainder of his piece to suggesting that the Copyright Restatement Project's use of the traditional common law restatement methodological approach could be understood by analogy to a hypothetical restatement of the Comprehensive Environmental Liability and Response Act (CERCLA), the federal Superfund statute. He offered three examples. First, he noted that although "CERCLA does not explicitly state whether there should be joint and several liability, the existence of a contribution provision in the statute has been interpreted to mean that, at least in some cases, joint and several liability must apply." 185 His second example concerned "a situation in which the statutory text is specific rather than open-ended." 186 He explained how courts, applying tools of statutory construction, had interpreted "owner and operator of a vessel or a facility" to mean "owner or operator of a vessel or a facility." 187 His third example dealt with an ambiguous statutory definition.

In each of these examples, a look at the courts' modus operandi reveals exactly why a simple common law analysis (and framework) is insufficient in explaining how they arrived at their conclusions. The courts engage in statutory interpretation to ascertain what the legislature intended, even when presented with a delegation of lawmaking authority; and in discharging that task, they scrutinize the clarity of the text, the pertinent legislative history, applicable canons of statutory construction, and other tools that are largely foreign to common law jurisprudence. Revesz's environmental law casebook highlights the centrality of this nuanced methodology. ${ }^{188}$ It reveals rather significant if not stark differences between common law adjudication and statutory interpretation.

185. Revesz, Federal Statutes, supra note 33, at 3.

186. Id.

187. Revesz explained the reasoning for this conclusion as follows:

First, the 'owner and operator' provision is immediately followed by a provision establishing liability for those who previously 'owned or operated a facility, and courts have read both provisions disjunctively rather than assuming that Congress intended a different result for current owners than for prior owners. Second, the fact that the statute contains a definition of 'owner or operator,' but not of either term standing alone, serves as further evidence for this disjunctive reading.

Id. This is a great illustration of the opposite of Revesz's suggestion that common law development and statutory interpretation are basically the same. Courts' reading of the statute is essentially an outcome of applying a canon of statutory construction contained in the maxim noscitur a sociis, i.e., a word is known by the company it keeps. The Supreme Court has validated and applied this canon to avoid giving "unintended breadth" to statutory provisions, which is precisely the logic here. See Jarecki v. G.D. Searle \& Co., 367 U.S. 303, 306-07 (1961). This is not an example of common law or common law-like interpretation, but rather statutory construction.

188. See Richard L. Revesz, Michael A. LiVermore, CAROline CECOT \& JAYNi Foley Hein, ENVIRONMENTAL LAW AND POLICY 849-50 (4th ed. 2019) [hereinafter REVESZ ET AL., ENVIRONMENTAL LAW \& POLICY]. As an illustration, consider the casebook's treatment of the joint and several liability 
There is a further reason why CERCLA is not the best analogy for restating copyright law. Unlike the Copyright Act of 1976, which underwent thorough vetting over two decades resulting in a voluminous legislative history, CERCLA was " "an eleventh hour compromise' passed without the benefit of committee reports concerning the compromise." 189 Nonetheless, as reflected above, even CERLCA's relatively sparse legislative history plays a substantial role in courts' interpretation of the statute. ${ }^{190}$ The role of legislative history is even more significant in courts'

question, where Revesz argues that the "scope of judicial discretion is essentially unconstrained by the statutory text." Revesz, Federal Statutes, supra note 33, at 3. To arrive at the premise of such broad interpretive discretion, courts had to first interpret the statute and Congress's legislative intent as affording them such latitude. A common law court, by contrast, would cut straight to the chase. See, e.g., United States v. Chem-Dyne Corp., 572 F. Supp. 802 (S.D. Ohio 1983) ("[T]he Court finds the language ambiguous with regard to the scope of liability. Consequently, in an attempt to discern the Congressional intent, the Court will review and weigh the legislative history of the Act. .."; "A reading of the entire legislative history in context reveals that the scope of liability and term joint and several liability were deleted to avoid a mandatory legislative standard applicable in all situations which might produce inequitable results in some cases. The deletion was not intended as a rejection of joint and several liability.”) (excerpted in Revesz ET AL., ENVIRONMENTAL LAW \& POLICY, supra, at 849-50). The casebook text explains the issue as follows:

CERCLA does not explicitly impose joint and several liability on PRPs. Courts, however, have routinely held PRPs jointly and severally liable. They have relied both on common law principles and on strong indications that Congress intended for joint and several liability to apply in at least some circumstances. See S. REP. 96-848 (1980).

The legislative history of CERCLA reveals that Congress contemplated that liability under CERCLA would be joint and several. Rather than impose joint and several liability in all cases by setting a statutory standard of liability, however, Congress chose to leave the standard of liability to the courts, with the understanding that common law principles would dictate the imposition of joint and several liability in most cases. See United States v. Chem-Dyne Corp., infra.

More recent amendments to CERCLA confirm this conclusion. The right to contribution contained in $\S 113$, which was passed as part of the SARA Amendments in 1986, clearly demonstrates that Congress intended for PRPs to be held jointly and severally liable in at least some circumstances - a right to contribution is only necessary if PRPs may be held liable for more than their individual share of response costs. Id. at 848 .

189. New York v. Shore Realty Corp., 759 F.2d 1032, 1040 (2d Cir. 1985); see also LansfordCoaldale Joint Water Auth. v. Tonolli Corp., 4 F.3d 1209, 1221 (3rd Cir. 1993) (noting that CERCLA is a "statute notorious for its lack of clarity and poor draftsmanship"); Developments in the Law-Toxic Waste Litigation, 99 HARV. L. REV. 1458, 1465 \& n.1 (1986) (explaining that "Congress enacted CERCLA ... just over one month after Ronald Reagan defeated incumbent President Jimmy Carter in the presidential election. Noting that Congress passed the statute during a 'lame duck' administration, former EPA Administrator Douglas M. Costle termed CERCLA's enactment 'an extraordinary action.'” (citation omitted)).

190. See supra note 188 (discussing Chem-Dyne Corp.); see also Chem-Dyne Corp., 572 at 805 (noting that "[i]t is proper to assume Congress was aware of the judicial interpretation of [33 U.S.C. $\S 1321$, a provision of the Federal Water Pollution Control Act] as a strict liability standard. Cannon v. University of Chicago, 441 U.S. 677, 696-97 (1979). In fact, the legislative history of the statute directly supports this finding. 126 CONG. REC. S14964 (Nov. 24, 1980), H11787 (Dec. 3, 1980).”). 
(and scholars') interpretation of other environmental law statutes, ${ }^{191}$ as well as amendments to CERCLA. ${ }^{192}$

To be sure, different parts of CERCLA are accorded different interpretive discretion by courts, yet they unquestionably see their discretion as interpretive. And in interpreting the statute, courts draw extensively on the text and structure of the statute, its legislative history and other accompanying sources used to ascertain Congressional intent, rather than just using precedent. The point is not merely that courts have latitude to go beyond what is expressed in the text, for they clearly do; but rather that in so doing, they see themselves as doing something qualitatively different from a common law court. While the result may appear no different to the untrained eye, it is the process of reasoning that justifies and legitimates the decision. Cabining this process into the traditional mold of the common law misapprehends the analytical process and undermines the legitimacy of the enterprise.

Revesz then concluded his defense of treating statutory Restatements like common law Restatements with the statement that: "what a Restatement in a statutory area should do is to provide the best interpretation of particular statutory provisions, which is exactly the inquiry that a court would engage in."193 While that is certainly an acceptable path for Restatements in statutory domains, it requires recognizing that courts arrive at their conception of the "best interpretation" using a myriad of sources and interpretive methods. And thus, if a statutory restatement purported to do "exactly" what courts do, then it would need to address their

191. See, e.g., Whitman v. Am. Trucking Ass'n, 531 U.S. 457, 490 (2001) (Breyer, J., concurring in part and concurring in the judgment) ("Here, legislative history, along with the statute's structure, indicates that $\S 109$ 's language reflects a congressional decision not to delegate to the agency the legal authority to consider economic costs of compliance."); Indus. Union Dep't, AFL-CIO v. Am. Petroleum Inst., 448 U.S. 607, 641, 708, 710 (1980) ("both the language and structure of the Act, as well as its legislative history, indicate that it was intended to require the elimination, as far as feasible, of significant risks of harm"; "the plurality's reasoning is refuted by the Act's language, structure, and legislative history"; "The plurality's interpretation of the 'reasonably necessary or appropriate' clause is also conclusively refuted by the legislative history."); Nat'l Ass'n of Home Builders v. Babbitt, 130 F.3d 1041, 1050 (D.C. Cir. 1997) ("In evaluating the effect of the regulated activity on interstate commerce, I begin ... with the legislative history of the Act under challenge."); E. Donald Elliott, Bruce A. Ackerman \& John C. Millian, Toward a Theory of Statutory Evolution: The Federalization of Environmental Law, 1 J.L. ECON. \& ORG. 313, 331 (1985) (observing that "Senator Muskie's pending bill to have the federal government set emission standards for motor vehicles was amended to provide that standards would be set by HEW, rather than in the legislation itself, and legislative history was written to leave no doubt that more stringent state laws were preempted"); Nat. Res. Def. Council v. Train, 545 F.2d 320, 324 (2d Cir. 1976) ("The issue is one of statutory construction. ... [T] [Te interpretation of the Clean Air Act advanced by the EPA is contrary to the structure of the Act as a whole, and that if accepted, it would vitiate the public policy underlying the enactment of the 1970 Amendments as set forth in the Act and in its legislative history.").

192. See, e.g., United States v. Pacific Hide \& Fur Depot, Inc., 716 F. Supp. 1341, 1348 (D. Idaho 1989) ("The legislative history behind the [Superfund Amendments and Reauthorization Act (1986)] shows that commercial transactions are to be treated differently than private transactions and inheritances. See 1986 U.S.S.C.A.N. 2835, 3279-3280. In fact, that legislative history establishes a three-tier system: Commercial transactions are held to the strictest standard; private transactions are given a little more leniency; and inheritances and bequests are treated the most leniently of these three situations.").

193. Revesz, Federal Statutes, supra note 33, at 3. 
interpretive methodology, which courts routinely do as part of their reasoning. ${ }^{194}$ Revesz's own conclusion therefore contradicts his suggestion of seamlessness between common law adjudication and statutory interpretation. The resistance to developing a more appropriate model for statutory Restatements was - and is difficult to fathom.

The confusion and distrust caused by the methodological mismatch grew as new drafts emerged. Adviser meetings grew increasingly contentious.

As the first Copyright Restatement Council Draft was headed to the ALI Council for approval, we submitted comments addressing the need to adapt the restatement model in order to fit the statutory restatement context:

We write as ALI members who are actively involved in the Institute's Restatement of the Law of Copyright to offer constructive feedback on the project and suggest important modifications to the Restatement of Copyright and future analogous projects (restatements of detailed statutes) aimed at fostering the ALI's mission "to promote the clarification and simplification of the law."

We begin by recognizing the important role that the ALI's Restatements have played in the American legal landscape. They have served as influential sources for courts, lawyers and law students; and have helped to synthesize and reconcile often-conflicting strands of analysis in different subject areas. At their inception, the Restatements focused entirely on judge-made common law and in the process facilitated the development of a relatively homogenous "American common law" despite the existence of variations across individual state laws in numerous areas.

With the proliferation of statutory law in myriad legal fields, the need has emerged for expert bodies such as the ALI to turn their attention to the interpretation and construction of statutes, many of which are highly complex and structurally reliant on judicial clarification through individual cases. In this respect, statutes retain a significant common law element. We therefore commend the ALI for turning its attention to restating statutory areas of law. Copyright law is a complex area that would certainly benefit from greater clarity in its rules and principles.

All the same, we urge the ALI to recognize that its move towards restating copyright law (intended be a comprehensive codification) is unprecedented and therefore worthy of significant reformulation in its extant methods of synthesis and restatement. Without that reformulation, we remain concerned that the task of restating an area of law covered

194. Indeed, this is even true in the illustrations that Revesz uses to illustrate how a statutory restatement would resolve a statutory ambiguity that has produced an unresolved circuit split. Id. Both courts that he cites describe their interpretive methodology and sources explicitly as part of their reasoning. See Nurad, Inc. v. William. E. Hooper \& Sons Co., 966 F. 2d 837, 844-47 (4th Cir. 1992) ("We think the district court's restrictive construction of 'disposal' ignores the language of the statute, contradicts clear circuit precedent, and frustrates the fundamental purposes of CERCLA.”); United States v. CDMG Realty Co., 96 F. 3d 706, 714-19 (3d Cir. 1996) ("A thorough examination of the text and structure of CERCLA convinces us that the passive migration of contaminants alleged here does not constitute disposal. Our conclusion is based on the plain meaning of the words used in the disposal definition and is supported by the structure of CERCLA's liability scheme. We also believe that our interpretation is consistent with CERCLA's purposes."). In neither case does the court simply adopt a position on the question as representing best policy. Rather, each does so only as a matter of appropriate interpretation based on pertinent sources. 
by a statute will engender additional confusion and disagreement among courts and jurists, and could thus undermine the ALI's core mission. ${ }^{195}$

As illustrated in Figure 1, we proposed beginning each section of the Copyright Restatement with a verbatim and complete recitation of the applicable Copyright Act text rather than "black letter law." A lot of the discussion during the first few years focused on trying to paraphrase and tweak what is in the statute. We felt that the Restatement should always have the statutory text front and center, which it was of course at liberty to then interpret and glean meaning from.

Figure 1: Proposed Statutory Restatement Template

Traditional (Common Law) Restatement Template:

1. "Black Letter" Law

2. Comments

- Illustrations

\section{Reporters' Notes}

Proposed Statutory/Common

Law Restatement Template:

1. Statutory Text

2. Interpretation

- Legislative Sources:

- Statutory Text

- Legislative History

- Statutory Purposes

- Administrative (C) Office)

- Jurisprudence

3. Comments

- Illustrations

4. Reporters' Notes

We proposed inserting a statutory interpretation layer explaining the authoritative and relevant sources for interpreting the statutory text and other aspects of copyright law, such as legislative history, administrative sources (including the U.S. Copyright Office Compendium), and, of course, jurisprudence. In common law contexts, these sources are limited to prior precedent. By contrast, we wanted to replicate the process by which judges interpret statutes, and here specifically copyright law. The interpretation layer would be followed by Comments and Reporters' Notes, just as with common law Restatements. The modification - as seen in Figure 1-was fairly modest and involved nothing particularly controversial in light of how courts actually approach copyright adjudication. And yet, it was rebuffed.

195. See Letter from Shyamkrishna Balganesh, Graeme Dinwoodie, Peter S. Menell, and David Nimmer to the ALI Council (Jan. 11, 2018), reproduced in June M. Besek, Peter S. Menell, Irene Calboli, Devlin Hartline, Justin Hughes, Pierre N. Leval, and William F. Patry, The ALI Copyright Restatement Project: A Horse of a Different Color?, Proceedings of the Twenty-Sixth Annual Conference International Intellectual Property Law \& Policy, Fordham University School of Law Skadden Conference Center, New York, New York, April 6, 2018, at 21-23. 
When presented with the proposal, the ALI Council established "a group" to evaluate our proposal and to offer recommendations. ${ }^{196}$ We were led to believe that we would be given an opportunity to present our views to the group (which turned out to be the ALI's "Projects Committee"), but no such opportunity emerged. The group met in secret with little external input, and merely recommended that the Restatement's black letter selectively incorporate actual language from the text of the statute and put quotation marks around the selections. Absolutely no changes were recommended in the general format of the Restatements, nor was there any engagement with the differences between statutory interpretation and common law development.

The lack of a coherent framework has continued to undermine the Copyright Restatement Project. ${ }^{197}$ As the next Section illustrates, it has undermined the coherence and objectivity of the enterprise.

\section{Entrenching the Mismatch: A Case Study of the Restatement's Treatment of the Distribution Right}

The process of addressing statutory interpretation in the Copyright Restatement Project has been made especially difficult by the failure to address the differences between common law development and statutory interpretation at the outset of the project. We should not be taken to suggest that the project has not reached sensible clarifications for some aspects of copyright law. Many provisions of the Copyright Act are straightforward, clear, and not significantly affected by advances in technology. In other cases, Congress incorporated common law standards and expressed an intention for courts to perpetuate the common law evolutionary process. But a third category of provisions - those requiring courts to interpret provisions drafted toward the beginning of the transition from the analog to the digital agepose the most significant challenge and are especially hamstrung by the lack of a Restatement format geared toward statutory interpretation.

For nearly all aspects of the Copyright Act of 1976, the legislative drafters convened large stakeholder meetings to discuss the crafting of provisions, and the Copyright Office produced detailed reports explaining the drafting process as well as the purposes and intention behind particular provisions. It is these provisions for

196. January Council Meeting Updates, supra note 29. The announcement read:

After discussion of the project at the 2018 January Council meeting, the Director agreed to designate a group to consider whether this project should use a format that differs from the typical Restatement format (see posted comment from Professors Balganesh, Dinwoodie, Menell, and Nimmer). The Director has asked the Projects Committee to perform this function.

197. See Letter from Shyamkrishna Balganesh, Peter S. Menell \& David Nimmer, to ALI Council, Re: Restatement of the Law Copyright, Council Draft No. 2 (Oct. 8, 2018) (reiterating that "[b]y not elucidating a methodological approach before drafting, the Restatement of Copyright lacks a stable foundation for building an objective resource for judges and practitioners"). 
which the common law Restatement template is particularly inapt. The Copyright Act's distribution right provides a good example of such a provision. ${ }^{198}$

We explore the effort to "restate" the Copyright Act's distribution right, as it illustrates the mismatch problem clearly. We begin by setting the stage and then work chronologically through the process that has unfolded.

\section{a. Background}

Prior to the emergence of peer-to-peer technology, the Copyright Act's distribution right was largely dormant. ${ }^{199}$ Most enforcement actions were premised upon violations of the reproduction right and the relatively rare cases invoking the distribution right involved arcane scenarios, such as placement of a copyrighted work in a library collection without authorization.

Following the rise of file sharing in the early 2000 s, the distribution right came into the spotlight. The major recording companies sued thousands of individuals alleged to be distributing sound recordings through peer-to-peer networks. The courts were inundated with cases involving individuals who placed copyrighted works in publicly accessible share folders. The copyright owners traced these files by searching for artist and song names through peer-to-peer networks.

Whereas the 1909 Act expressly protected the rights to "publish" and "vend,"200 the 1976 Act speaks of a right to "distribute." 201 Interpreting "distribute" narrowly, some courts held that copyright owners must prove that a sound recording placed in a share folder was actually downloaded by a third party to establish violation of the distribution right. ${ }^{202}$ Other courts held that merely making a sound recording available through a peer-to-peer network share folder violates the distribution right. ${ }^{203}$ Still other courts considered the offering to distribute a work to be actionable. $^{204}$

198. The 1976 Copyright Act defines the distribution right thusly: "[T]he owner of copyright under this title has the exclusive rights to do and to authorize any of the following: ... to distribute copies or phonorecords of the copyrighted work to the public by sale or other transfer of ownership, or by rental, lease, or lending ....” 17 U.S.C. § 106(3).

199. See generally Menell, Copyright's Lost Ark, supra note 24 (tracing the crafting of the 17 U.S.C. $\S 106(3)$ right to distribute).

200. 1909 Act $\S 1$.

201. 17 U.S.C. $§ 106(3)$.

202. See, e.g., Capitol Records, Inc. v. Thomas, 579 F. Supp. 2d 1210, 1218 (D. Minn. 2008) (requiring proof of downloading to violate the distribution right); Atl. Recording Corp. v. Howell, $554 \mathrm{~F}$. Supp. 2d 976, 981 (D. Ariz. 2008) (same); Atl. Recording Corp. v. Brennan, 534 F. Supp. 2d 278, 282 (D. Conn. 2008) (same); London-Sire Records, Inc. v. Doe 1, 542 F. Supp. 2d 153, 169 (D. Mass. 2008) (same, but considering downloading by forensic investigator to be sufficient).

203. See, e.g. A\&M Records, Inc. v. Napster, Inc., 239 F.3d. 1004, 1014 (9th Cir. 2001) (not requiring proof of actual distribution); Universal City Studios Prods. LLP v. Bigwood, 441 F. Supp. 2d 185, 190 (D. Me. 2006) (same); Arista Records LLC v. Greubel, 453 F. Supp. 2d 961, 968 (N.D. Tex. 2006) (same); Warner Bros. Records v. Payne, No. W-06-CA-051, 2006 WL 2844415, at *3-11 (W.D. Tex. July 17, 2006) (same).

204. See, e.g., Elektra Ent. Grp., Inc. v. Barker, 551 F. Supp. 2d 234 (S.D.N.Y. 2008) (equating distribution and publication). 
The ramifications of this interpretive issue for copyright enforcement in the internet age are substantial. Under the narrow interpretation, the relative anonymity of internet transmissions in combination with privacy concerns make enforcement costly and difficult. In contrast, a broad interpretation exposes millions of file sharers to potentially crushing statutory damages for simply making a work available for download. ${ }^{205}$

Given that courts rarely confronted the meaning of the 1976 distribution right prior to the emergence of peer-to-peer technology, the copyright treatises of this era provided little insight into origins of the "distribution" right. ${ }^{206}$ Attorneys for the parties in the mounting wave of peer-to-peer file-sharing cases offered judges little insight into the critical question of why Congress shifted terminology from "publish" and "vend" to "distribute."

\section{b. Drafting History of the $\S 106(3)$ Distribution Right}

In 2010, one of this Article's authors traced the reason for the shift in terminology. ${ }^{207}$ That research unequivocally revealed that Congress intended to perpetuate the traditional rights to "publish" and "vend" in its crafting of the $\S 106(3)$ distribution right. The 1961 Register's Report states that the drafting committee proposed "to retain the exclusive rights given to copyright owners under the present [1909] law - to make and publish copies, to make new versions, to give public performances, and to make recordings". ${ }^{208}$ The shift to the "distribution" formulation occurred in late 1962. As Abe Goldman, the Copyright Office General Counsel who led the drafting effort, stated at the 1963 House Judiciary Committee hearing, the somewhat prolix language in 17 U.S.C. § 106(3) was intended to "broaden," not narrow, the publish and vend rights. ${ }^{209}$

The legislative hearing explained the straightforward and logical rationale for the change in the terminology, which would have been unmistakable and clear to the copyright experts involved in the drafting process. Under the 1909 Act, publishing a work without proper notice injected a work into the public domain. To avoid such

205. The Copyright Act's remedial regime is arguably out of kilter. See Peter S. Menell, This American Copyright Life: Reflections on Re-Equilibrating Copyright for the Internet Age, $61 \mathrm{~J}$. COPYRIGHT SOC'Y U.S.A. 235, 302-07 (2014). However, there is no indication that Congress intended courts to take that into consideration in interpreting the scope of copyright law's exclusive rights.

206. See Menell, Copyright's Lost Ark, supra note 24, at 7-10 (2011).

207. See id. at 30-66.

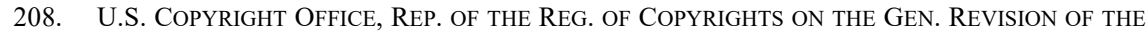
U.S. COPYRIGHT LAW, at x (July 1961) [hereinafter 1961 Register's Report] (emphasis added).

209. See id. at 42 (quoting StAFF OF H. COMM. ON THE JudiCIARY, 88TH CONG, COPYRIGHT LAW REVISION, PART 3: PRELIMINARY DRAFT FOR REVISED U.S. COPYRIGHT LAW AND DisCUSSIONS AND COMMENTS ON THE DRAFT 109-10 (Comm. Print 1964), reprinted in 3 OMNIBUS COPYRIGHT REVISION LEGISLATIVE HistORY (1976)). The full quotation states:

Subsection (b) [what would become $\S 106(3)$ ], I believe, would cover everything that's covered in section 1(a) of the present law [1909 Act] by reference to the terms "publish" and "vend"broadened, I would say, to avoid any questions as to whether "publish" or "vend" is used in such a narrow sense that there might be forms of distribution not covered. I think the draft covers virtually all forms of distribution. 
dire consequences, courts had interpreted "publish" in confusing ways. Edward Sargoy, the ABA representative, stated that the rationale for the wording change was merely to avoid the confusion created by that jurisprudence:

I am heartily in accord with the omission of the use of the words "published" or "publication." I think that the use of the words "publication" or "published," in hundreds of common law and statutory cases, dissertations, and otherwise, has made the terms archaic today in the light of our recent technological progress. Reference to such materials where the word derived its meaning from conditions existing in the 18th, 19th, and early part of the 20th century, will only lead to confusion. I think it is an excellent idea to use the word "distribute" and, just as the draft here has done, have "distribute" expressly include the right "to sell," (which is strictly one of the rights of publication), "or otherwise transfer ownership of, rent, lease, or lend one or more copies or sound recordings of the work." 210

This explanation should remove any doubt about Congress's intent in replacing "publish" and "vend" with "distribute." Congress sought to perpetuate the longstanding publish and vend rights, but in a way that sidestepped the jurisprudential morass surrounding the term "publish." There was no intention to narrow the historic and fundamental publish and vend rights. As Abe Goldman highlighted, the express intention was to broaden those rights.

There are numerous other indications that Congress intended to perpetuate the traditional publish and vend rights and in no way sought to narrow their scope. Notably, the definition of "publication" encompasses "[t]he offering to distribute copies or phonorecords to a group of persons for purposes of further distribution, public performance, or public display, constitutes publication."211 This language can be understood against the backdrop of the Sound Recording Amendments Act of 1971 and the ratification of the Geneva Phonogram Convention, which reinforce Congress's intention that "distribute" encompasses "offering to distribute." 212

The general legislative history of the 1976 Act further supports a broad interpretation of the right to distribute. ${ }^{213}$ The 1965 Supplementary Report recognized the need to guard against "confining the scope of an author's rights on the basis of the present technology so that, as the years go by, his copyright loses much of its value because of unforeseen technical advances." 214 The Report then cites "these reasons" for stating the exclusive rights in "broad terms." Then, in an extraordinarily prescient statement, the drafters noted that "it is becoming increasingly apparent that the transmission of works by ... linked computers, and other new media of communication, may soon be among the most important means of disseminating them, and will be capable of reaching vast audiences," and that "the

210. Id. at 128 .

211. 17 U.S.C. $§ 101$ (definition of "publication") (emphasis added); see also Menell, Copyright's Lost Ark, supra note 24, at 48-50 (tracing the crafting of the definition of "publication").

212. See Menell, Copyright's Lost Ark, supra note 24, at 48-51 (shedding light on the interplay of "distribute to the public," "distribution to the public," and "offering to the public").

213. See id. at 62-63.

214. StafF OF H. COMm. ON the Judiciary, 89Th CONG., Copyright LaW Revision, Part 6: SUPPLEMENTARY REPORT OF THE REGISTER OF COPYRIGHTS ON THE GENERAL REVISION OF THE U.S. COPYRIGHT LAW: 1965 Revision Bill 19 (Comm. Print 1965). 
day is past when any particular use of works should be exempted for the sole reason that it is "not for profit."'215

\section{c. Putting the § 106(3) Jurisprudence in Context}

As copyright enforcement litigation unfolded following the filing of thousands of infringement cases against individual file sharers, courts were confronted with the scope of the distribution right on an unprecedented scale. As noted above, the handful of prior cases were not particularly illuminating, treatises and law reviews did not confront the issue in any depth, and the litigators were not aware of the $\S 106(3)$ legislative history. Neither the parties' lawyers nor the amici briefs filed in these cases presented courts with the legislative history of the provision. Judges thus were left in the dark as to the scope of "distribute" and why Congress changed the wording of the historic rights to "publish" and "vend" to a right to "distribute."

Therefore, it is not surprising that judges struggled to interpret $\S 106(3)$. Busy judges and even the most conscientious law clerks were not likely to parse hearings and records stretching back to the earlier 1960s. The documents were buried, and the judges would expect the party representatives to call these sources to their attention. ${ }^{216}$ Furthermore, even if an adventurous law clerk had located the pertinent documents, the clerk might not have been able to appreciate the then-raging controversy over publication without affixing proper notice that plagued the 1909 Act jurisprudence. The cases that encountered the issue divided relatively evenly on whether or not actual downloading of a file made available through a file-sharing service constituted a violation of $\S 106(3){ }^{217}$ None of the cases cited or discussed the legislative history explaining Congress's word choice.

By the time Copyright's Lost Ark unearthed and explained the legislative history of the provision, much of the Recording Industry Association of America (RIAA)led litigation had subsided. ${ }^{218}$ Since that time, the Tenth Circuit had occasion to rule on the question of whether $\S 106(3)$ encompassed a "making available" right. The plaintiff called the court's attention to Copyright's Lost Ark, and to the updated treatment of the issue in Nimmer on Copyright, which was based on that article. ${ }^{219}$

215. See id.

216. The volumes in which these reports and transcripts reside are not readily available. They are part of the two compilations of legislative history of the Copyright Act of 1976. See KAMINSTEIN LEGISLATIVE History PROJECT: A COMPENDIUM AND ANALYTICAL INDEX OF MATERIALS LEADING TO THE COPYRIGHT ACT OF 1976 (Alan Latman \& James F. Lightstone eds., 1981) (6 vols.); OMNIBUS COPYRIGHT REVISION LEGISLATIVE HISTORY (George S. Grossman ed., 2001) (17 vols.). Both can be found in major research libraries and the HeinOnline archive, but are quite large and not easily searchable.

In addition, they cannot be adequately understood through keyword searching or the indices.

217. See supra notes 202-204.

218. See Sarah McBride \& Ethan Smith, Music Industry To Abandon Mass Suits, WaLl St. J. (Dec. 19, 2008), https://perma.cc/ZDY6-YRBT.

219. See 2 Melville B. Nimmer \& DAVID NimMBER, NimMER ON COPYRIGHT $\S 8.11$ (incorporating major portion of Copyright's Lost Ark). We note that two commentators questioned David Nimmer's updating of his treatise to reflect this research. See Ann Bartow, A Restatement of Copyright Law as More Independent and Stable Treatise, 79 BROOK. L. REV. 457, 483-86 (2014); Rick Sanders, 
Drawing on that analysis, the appellate court interpreted § 106(3) to encompass a making available right. ${ }^{220}$ The Tenth Circuit's opinion remains the only appellate court decision to have addressed the issue after the legislative history became known.

Moreover, at the request of the House Subcommittee on Courts, Intellectual Property \& the Internet, the Copyright Office undertook a comprehensive study of the issue beginning in early $2014 .{ }^{221}$ The Office solicited comments from the public and held hearings on May 5, 2014. ${ }^{222}$ The Copyright Office issued a comprehensive report in February 2016, stating that, "[c]onsistent with its prior analyses and testimony, as well as the views of Congress, multiple Administrations, appellate courts, and leading academic authorities, the Copyright Office concludes that the exclusive rights of copyright owners set forth under 17 U.S.C. § 106 collectively meet and adequately provide the substance of the making available right."223

\section{d. The Restatement of Copyright Enters the Fray}

The Restatement of Copyright reporters took up the $\S 106(3)$ distribution right in Preliminary Draft No. 6 ("PD6"), made available on August 12, 2020.224 Section 6.04 addresses "The Copyright Owner's Exclusive Right to Distribute Copies or Phonorecords of the Work to the Public."

Rather than explain the controversy surrounding the provision, its historical context, and the pertinent legislative history, PD6 $§ 6.04$ confused the issues by mischaracterizing the landscape of district court decisions rendered prior to the issuance of the Copyright Office Report, and altogether sidestepped the key interpretive questions by suggesting they were unimportant.

Instead of engaging the legislative history of the distribution right, the Restatement chose to limit itself principally to the case law on the provision. Even there, it mischaracterized the jurisprudence. Section 6.04 Comment $d$ stated that

Will Professor Nimmer's Change of Heart on File Sharing Matter, 15 VAND. J. ENT. \& TECH. L. 857 (2013). As Copyright's Lost Ark explains, no one had traced this issue to its origins. See Menell, Copyright's Lost Ark, supra note 24, at 20-30; see also id. at 25, 39-51 (suggesting that the reason for this issue escaping attention was that prior to the internet, violations of the distribution right went hand in hand with violations of the reproduction right and that the critical documents were buried in a lost ark of legislative history). When that research revealed the explanation for the substitution of the word "distribute" for "publish" and "vend" and the intention behind the wording change, Nimmer saw fit to update his treatise, just as any careful judge or scholar should do. The authors of those commentaries fail to address the substance of the analysis. With the benefit of extensive comments and hearings, the Copyright Office tested this research and found it to be persuasive. See U.S. Copyright Office, The MAKING AVAILABLE Right IN THE UNITED STATES: A REPORT OF THE REgISTER OF COPYRIGHTS (Feb. 2016) (hereinafter "COPYRIGHT OFFICE MAKING AVAILABLE REPORT").

220. See Diversey v. Schmidly, 738 F.3d 1196, 1202 (10th Cir. 2013).

221. See Letter from Rep. Melvin L. Watt, Ranking Member, Subcomm. on Cts., Intell. Prop., \& the Internet, H. Comm. on the Judiciary, to Maria A. Pallante, Reg. of Copyrights and Dir., U.S. Copyright Off. (Dec. 19, 2013).

222. See U.S. Copyright Office, Study on the Right of Making Available, Comments and Public Roundtable, 79 Fed. Reg. 10,571 (Feb. 25, 2014).

223. See Copyright Office Making Available Report, supra note 219, at 4.

224. Restatement of the Law, Copyright § 6.04, at 86 (AM. L. InSt., Preliminary Draft No. 6 , Aug. 12, 2020) [hereinafter Restatement Preliminary Draft No. 6 (2020)]. 
"[m]ost courts have held that actual dissemination or transmission of at least one copy or phonorecord of a copyrighted work is necessary in order to infringe the distribution right in that work, and that a mere offer to disseminate or transmit copies or phonorecords, or the act of making copies and phonorecords available to the public, does not infringe the distribution right." 225 As noted above, the cases were relatively evenly divided. ${ }^{226}$

Far more importantly, the district court decisions cited in PD6 $\S 6.04$ were all rendered without an awareness of the pertinent legislative history, and before the Tenth Circuit's Diversey decision. ${ }^{227}$ Thus, the pre-2010 jurisprudence needed be viewed skeptically, not held out as authoritative. In any event, once that pertinent legislative history came to light, the Tenth Circuit cited that research to hold that 17 U.S.C. § 106(3) encompasses a "making available" right. ${ }^{228}$ That pronouncement sets the stage for a proper restatement of governing law, as it is the only informed appellate pronouncement on the subject, and it stands in opposition to the various rulings from non-precedential courts that PD6 cites. Moreover, it reflects more fully the circumstances leading to the adoption of $\S 106(3)$, as opposed to the earlier decisions that did not consider that vital material.

While we believe that the correct position on the question is based on a careful analysis of the text, an assessment of textual ambiguity, and the legislative history as described in Copyright's Lost Ark, it bears emphasizing that our point here is not that PD6 chose to adopt a different position. In the context of the common law, Restatements of Law are permitted to deviate from a majority rule when it is seen as "outmoded or undesirable," following the Restatements' adoption of the voice of an "excellent common-law judge."229 Yet, the treatment of the issue in PD6 presented two independent problems.

First, PD6 refrained from taking a position altogether, contrary to the ALI's own unequivocal admonition that a Restatement "needs to be clear about what it is doing" and that Reporters are expected to recommend what they see as a "better rule" when a conflict among options exists. To do otherwise would defeat the very purpose of a Restatement and do little to clarify the law. Indeed, Revesz's own defense of restating federal statutes suggested that one clear purpose of the enterprise was to resolve circuit splits and "conflicting lines of precedent."230

Somewhat surprisingly, PD6 $\S 6.04$ sidestepped the key interpretive questions on the following basis: "Given the depth of division over the 'making available' right, and the substantial and largely counterbalancing arguments on both sides, this Restatement does not take a position - in part because the issue's practical import is slight relative to the controversy surrounding it."231 This observation is deeply

225. Id. $\S 6.04 \mathrm{cmt} . \mathrm{d}$, at 89 (emphasis added).

226. See supra notes 202-204.

227. See Diversey v. Schmidly, 738 F.3d 1196, 1202 (10th Cir. 2013).

228. Id. (citing Menell, Copyright's Lost Ark, supra note 24).

229. ALI, CAPTURING THE VOICE (2015), supra note 151, at 6.

230. Revesz, Federal Statutes, supra note 33, at 3.

231. See Restatement Preliminary Draft No. $6(2020) \S 6.04 \mathrm{cmt}$. d, at 89. 
problematic. Leaving to one side the issue of practical import, ${ }^{232}$ the Restatement refrains not only from taking a position, but also from explaining why it sees the arguments on both sides as counterbalanced, in other words, equally persuasive, except based on a banal, uncritical, and incomplete counting of cases. ${ }^{233}$

Despite claiming to refrain from taking a position, PD6 endorses a wooden textualist interpretation of $\S 106(3)$, appearing to take a position after all. Consider the following observation:

Along similar lines, the legislative history of the 1976 Copyright Act does suggest, as one commentator has noted, that Congress intended the 17 U.S.C. $\$ 106(3)$ right to be equivalent in scope to the exclusive right of the copyright owner under the 1909 Copyright Act to "print, reprint, publish, copy, and vend the copyrighted work," 1909 Act $\S 1(\mathrm{a})$, a right which courts had interpreted "to encompass the offering of copyrighted works to the public.” Menell, 59 J. COPYRIGHT SOC'Y U.S.A. at 238. However, the actual language of 17 U.S.C. $§ 106(3)$ replaced the terms "print, reprint, publish, copy, and vend" in the 1909 Copyright Act, and especially the word publish, which is capacious enough to encompass a "making available" right, with the language framing the copyright owner's right under $\S 106(3)$ of the 1976 Copyright Act as an exclusive right to make or authorize the "distribution of copies of phonorecords to the public." Thus, the language that Congress enacted may not reflect the intent suggested by the legislative history. ${ }^{234}$

232. Contrary to PD6, the issue is of significant import in litigation. The making-available interpretation saves significant resources and avoids needless discovery that risks invading the privacy of third parties (downloaders). The salient difference between recognizing or denying the existence of a making available component as part of the copyright owner's distribution right inheres in how file-sharing cases unfold in the courts. If that right is recognized, then proof of the plaintiff's case becomes straightforward: Once evidence has been presented that the defendant uploaded the totality of the copyrighted work in question, the plaintiff's case in chief is complete. At that point, expeditious procedures, such as summary judgment, can quickly resolve the entire case. By contrast, if the making available right is denied, then essentially every peer-to-peer upload case becomes a trying exercise in laborious discovery. The copyright owner, after identifying the uploader in question, needs to issue subpoenas to Internet Service Providers in order to furnish the identity of the subscribers behind the Internet Protocol addresses that have engaged in downloading from that user. Extensive monitoring is then required, in order to generate that list. After the subpoenas have issued, the copyright owners still need to slog through the type of extensive discovery disputes that have punctuated these proceedings in the past. Among the issues that judges across the country have confronted in peer-to-peer proceedings are the following: improper joinder and severance in the context of "swarms" from which a given copyrighted work is accessed by numerous users; whether personal jurisdiction and venue are properly asserted in the district in question against numerous downloaders scattered across the country; the need for specially tailored protective orders; when intervention is permitted to challenge the scope of the copyright owners' subpoenas; whether those subpoenas compromise their targets' rights of due process; and a hornet's nest of other procedural pitfalls relating to protecting user privacy. See 4 NIMMER ON COPYRIGHT, supra note 219, at §12B.09[A][4].

233. The counting is, additionally, uninformed. On one side are decisions rendered in the dark, reflecting a reading of $\S 106(3)$ founded on mistaken conjectures of what Congress might have had in mind. On the other side is an unequivocal explanation of Congress's actual intent, a clearly articulated rationale for using different terminology from the 1909 Act when drafting the 1976 Act, a Tenth Circuit decision based on that pertinent legislative history, and the culmination in the Copyright Office's thorough review and definitive report.

234. See Restatement Preliminary Draft No. 6 (2020) §6.04, reporters' note d, at 94-95. 
At best, this observation begs the question; it endorses the view that even though the legislative history suggests a clear intent, the language does not reflect such intent. Yet, the suggestion that the language does not reflect intent is precisely what an "ambiguous" statute entails, which requires resort to legislative history. Was PD6 taking a position or not? While proclaiming its neutrality, it appeared to be endorsing the rejection of legislative history - but without any explanation or justification.

Second, and related to the previous observation, just whose voice or perspective was the taken position meant to represent? In other words, in appearing to reject the reliance on legislative history for lack of ambiguity and preferring a textualist reading of the statute instead, PD6 purports to put itself in the role of a judge. And as is wellknown, federal judges interpreting statutes have discretion in choosing an interpretive methodology. Section 6.04 takes the Restatement's role-playing idea ("perspective of a common-law court") to heart in adopting the voice of a textualist judge on this one issue.

We see here the full folly and, indeed, perniciousness of the ALI's failure to modify its Restatement framework for federal statutes. Within the context of federal statutory law, adopting the perspective of an unfettered common law court cannot be translated into the Restatement without being interpretatively Janus-faced within the same statute: purposivist at times and textualist when not. This equivocation is highlighted by the fact that elsewhere PD6 turns to the legislative history as an interpretive tool and quotes an entire paragraph from that history to elucidate the meaning of "publication," 235 an issue closely allied with defining the scope of the distribution right. The draft invokes and relies on legislative history in discussing and interpreting many provisions of the Copyright Act. ${ }^{236}$

We filed detailed comments following the distribution of PD6, laying out the background of the $\S 106(3)$ distribution right, critiquing outright errors and omissions (as detailed above), and addressing the methodological problems that underlie the flaws of $\S 6.04 .^{237}$ We noted $\S 6.04$ 's not-so-subtle inclination against the existence of a making available right while nominally not taking a stance either

235. See id. $\$ 5.02 \mathrm{cmt}$. e, at 63.

236. See id. $\$ 3.10 \mathrm{cmt}$. i, at 31 (explaining termination rights); id. $\S 3.10 \mathrm{cmt}$. i, at 32 (highlighting that decisions are consistent with legislative history); id. $\S 3.10$, reporters' note a, at 35 (explaining the rationales for different termination provisions); $i d$. $\S 3.10$, reporters' note $\mathrm{k}$, at $40-41$ (quoting legislative history to explain legislative intent); $i d$. 5.02 , reporters' note c, at 61 (explaining the duration provision); id. $\S 5.02$, reporters' note d, at 62 (explaining duration for joint works; relying on the 1965 Register's Supplementary Report); id. $\S 5.02$, reporters' note f, at 63 (explaining duration for anonymous works, pseudonymous works, and works made for hire); $i d$. $\S 5.02$, reporters' note g, at 64 (explaining the rationale for extending duration to the ends of the year); id. § 5.03, reporters' note d, at 68-69 (explaining duration provisions); $i d$. $\S 6.0$, reporters' note a, at 77 (explaining the use of the phrase "to authorize"), id. $\S 6.02 \mathrm{cmt}$. d, at 81 (explaining the scope of the reproduction right); id. $\S 6.02 \mathrm{cmt}$. g, at $82-83$ (explaining the limited scope of the reproduction right with regard to sound recordings); $i d$. $\S 6.02$, reporters' note $\mathrm{d}$, at 83 (explaining the scope of the reproduction of right); id. $\S 6.02$, reporters' note e, at 83-84 (same); id. $\S 6.02$, reporters' note $\mathrm{f}$, at $84-85$ (explaining the limited scope of the reproduction right with regard to sound recordings); id. $\S 6.04, \mathrm{cmt}$. f, at 90 (explaining that references to "copies or phonorecords" include the singular); id. $\S 6.05$, reporters' note b, at 100 (explaining the importation right); id. $\S 6.06$, reporters' note d, at 110 (explaining Congress's intent regarding the first-sale limitation).

237. See Comments of Shyamkrishna Balganesh, Peter S. Menell, and David Nimmer on Restatement of the Law of Copyright, Preliminary Draft No. 6 (Sept. 10, 2020). 
way. Although the draft cites the Copyright Office's Making Available Report and Copyright's Lost Ark, it neither explains the analysis and key findings of those critical sources nor puts the jurisprudence into proper context. A judge, practitioner, or scholar reviewing $\S 6.04$ would, we believe, come away with a distorted view of $\S 106(3)$ of the Copyright Act, the legislative intent leading to its adoption, and the jurisprudence that has interpreted it. The fact that this is a likely possibility undermines the credibility of the whole enterprise.

We concluded our comments by emphasizing that judges approach the application of the Copyright Act through their own interpretive lens. All the same, it was not for the Restatement to dictate (or even suggest) a particular interpretive approach to adopt for different portions of the statute. The Restatement's task was to clearly and faithfully explain the pertinent text, legislative history, and jurisprudence surrounding the Copyright Act - and then leave it to the judge to choose the appropriate subset of sources to use during the interpretation of the term, including in the court's assessment of its ambiguity.

\section{e. The Adviser Meeting}

The ALI convened the adviser and MCG meeting to discuss PD6 on September 17, 2020. Although $\S 6.04$ was addressed in just one of the more than a dozen sections discussed, it took up approximately an hour of the meeting. We presented the arguments summarized above, highlighting how the Restatement needed to empower judges to make their own assessment of interpretive questions. We also noted how, contrary to some suggestions, the Supreme Court had routinely referred to the legislative history of the 1976 Act in interpreting its provisions. ${ }^{238}$ We

238. See Fourth Est. Pub. Benefit Corp. v. Wall-Street.com, LLC, 139 S.Ct. 881, 891 (2019); Star Athletica, L.L.C. v. Varsity Brands, Inc., 137 S.Ct. 1002, 1031-32 (2017) (Breyer, J., dissenting); Am. Broad. Cos., Inc. v. Aereo, Inc., 573 U.S. 431, 441-42 (2014); Kirtsaeng v. John Wiley \& Sons, Inc., 568 U.S. 519, 535, 539, 549-51 (2013) (Breyer, majority opinion) (relying on Committee hearings ("Irwin Karp of Authors' League of America expressing concern for 'the very basic concept of copyright law that, once you've sold a copy legally, you can't restrict its resale"; "then-Register of Copyrights, Abraham Kaminstein, found these examples 'very troubl[ing].' And the Copyright Office released a draft provision that it said 'deals with the matter of the importation for distribution in the United States of foreign copies that were made under proper authority but that, if sold in the United States, would be sold in contravention of the rights of the copyright owner who holds the exclusive right to sell copies in the United States" (citing to COPYRIGHT LAW REVISION DISCUSSION AND COMMENTS ON REPORT OF THE REGISTER OF COPYRightS ON THE GENERAL REVISION OF THE U.S. Copyright LAW, 88Th CONG., 1st SesS., (Comm. Print 1963)), and the 1965 Supplementary Report); id. at 568-73 (Ginsburg, dissenting) (relying on 1961 Register's Report, witness testimony at Copyright Office hearings, draft legislation, and 1965 Supplementary Report); Eldred v. Ashcroft, 537 U.S. 186, 195 (2003); N.Y. Times Co., Inc. v. Tasini, 533 U.S. 483, 495 (2001) (relying on pre-1976 legislative history); id. at 507-508 (2001) (Stevens, J., dissenting); Campbell v. Acuff-Rose Music, Inc., 510 U.S. 569, 577, 580, 584-85, 590 (1994); Feist Publ'ns, Inc. v. Rural Tel. Serv. Co., Inc., 499 U.S. 340, 354-55 (1991) (relying on 1965 Supplementary Report); Cmty. for Creative Non-Violence v. Reid, 490 U.S. 730, $743-48$ (1989) (tracing back the work made for hire doctrine to hearings and placing primary emphasis on the 1965 Report, quoting it repeatedly); Stewart v. Abend, 495 U.S. 207, 224, 229 (1990); Mills Music, Inc. v. Snyder, 469 U.S. 153, 159-61 (1985) (relying on 1965 Supplementary Report); Harper \& Row, Publishers, Inc. v. Nation Enters., 471 U.S. 539, 551 (1985); Sony Corp. of Am. v. Universal City Studios, Inc., 464 U.S. 417, $463-$ 67 (1984) (Blackmun, J., dissenting) (relying on 1965 Supplementary Report). 
concluded with the suggestion that the Restatement needed to begin with a clear statement about the role and importance of the legislative history to the interpretation of the Act. ${ }^{239}$

The discussion that followed broadly supported the logic and value of providing judges with an objective explanation of the crafting of statutory provisions to aid them in exercising their judgment in interpreting the Copyright Act.

\section{f. The Restatement of Copyright Makes Matters Worse}

The ALI released Council Draft 5 (“CD5”) on December 4, 2020, ${ }^{240}$ which made some corrections to $\S 6.04$ but continued to shade the presentation and did not address the core methodological concerns. To the contrary, some of the added material exacerbates those concerns.

In acknowledging that the distribution right case law was relatively evenly divided, CD5 replaced the word "most" with "some" in Comment $d$, but, surprisingly, not in the Reporters' Notes. ${ }^{241}$ It also eliminated the reference to the lack of "practical import" underlying the issue, which others had criticized as well. Yet, it continued with its position that there were "counterbalancing arguments on both sides," without offering any reasons or explaining how this approach meshed with the stated approach of resolving conflicts. ${ }^{242}$

Reporters' Note $d$ to $\S 6.04$ starts with a discussion of the cases, without ever acknowledging that, unlike in the common law, those cases were themselves interpreting the text, along with other materials. ${ }^{243}$ It would be far more useful to

239. This comment reinforces what scholars have chronicled. See James J. Brudney, Confirmatory Legislative History, 76 BROOK. L. REV. 901 (2011).

240. See Restatement of the Law, Copyright (Am. L. InSt., Council Draft No. 5, Dec. 4, 2020)

[hereinafter Restatement Council Draft No. 5 (2020)].

241. Id. $\$ 6.04 \mathrm{cmt} . \mathrm{d}$, at 109.

242. Id.

243. Reporters' Note $d$. reads in full:

$d$. Whether making a work available is sufficient to constitute distribution. For cases holding that actual distribution of copies or phonorecords is necessary to infringe the distribution right, see, e.g., Perfect 10, Inc. v. Google Inc., 508 F.3d 1146 (9th Cir. 2007); Nat'l Car Rental Sys., Inc. v. Computer Assocs. Int'1, 991 F.2d 426, 434 (8th Cir. 1993); Atl. Recording Corp. v. Howell, 554 F. Supp. 2d 976, 981 (D. Ariz. 2008) ("The general rule, supported by the great weight of authority, is that "infringement of [the distribution right] requires an actual dissemination of either copies or phonorecords."') (quoting Nat'l Car Rental, 991 F.2d at 434); Capitol Records, Inc. v. Thomas, 579 F. Supp. 2d 1210, 1223 (D. Minn. 2008); London-Sire Records, Inc. v. Doe, 542 F. Supp. 2d 153, 167-168 (D. Mass. 2008); In re Napster, Inc. Copyright Litig., 377 F. Supp. 2d 796, 805 (N.D. Cal. 2005); Guedes v. Martinez, 131 F. Supp. 2d 272, 277 (D.P.R. 2001). For cases holding that making copies or phonorecords available to the public is sufficient to support a claim under 17 U.S.C. § 106(3), see, e.g., Hotaling v. Church of Jesus Christ of Latter-Day Saints, 118 F.3d 199, 201 (4th Cir. 1997) (holding that "a library distributes a published work, within the meaning of the Copyright Act, when it places an unauthorized copy of the work in its collection, includes the copy in its catalog or index system, and makes the copy available to the public"). Accord Diversey v. Schmidly, 738 F.3d 1196, 1202 (10th Cir. 2013); Arista Records LLC v. Greubel, 453 F. Supp. 2d 961, 969-970 (N.D. Tex. 2006); Marobie-FL, Inc. v. Nat'l Ass'n of Fire Equip. Distribs., 983 F. Supp. 1167, 1173-1174 (N.D. Ill. 1997). 
judges were it to explain the background of the interpretive issue and trace the crafting of the provision. With that grounding, the judge (or practitioner, scholar, or student) would have a better foundation for understanding the jurisprudence. Such a methodological and organizational structure should be standardized across statutory restatements. Sadly, Reporters' Note $d$ reflects the poor initial choice to turn the interpretive inquiry into counting a smattering of district court cases that were not based on anything near a complete understanding of the legislative history.

It is, however, later in the same Reporters' Notes that CD5 further reinforces and exacerbates the Restatement's failure to address the issue of statutory interpretation. For context, this section is reproduced below, with the underlined portion reflecting the new material added:

There were statements made at congressional hearings in the 1960s and early 1970s that may suggest, as one commentator has noted, that Congress intended the 17 U.S.C. $\S 106(3)$ right to be equivalent in scope to the exclusive right of the copyright owner under the 1909 Copyright Act to "print, reprint, publish, copy, and vend the copyrighted work," 1909 Act $\S 1$ (a), a right which courts had interpreted "to encompass the offering of copyrighted works to the public." Menell, 59 J. COPYRIGHT SOC'Y U.S.A. at 238246. However, the actual language of 17 U.S.C. $\S 106(3)$ replaced the terms "print, reprint, publish, copy, and vend" in the 1909 Copyright Act, and especially the word publish, which is capacious enough to encompass a "making available" right, with the language framing the copyright owner's right under $\S 106(3)$ of the 1976 Copyright Act as an exclusive right to make or authorize the "distribution of copies of [sic] phonorecords to the public." Thus, the language that Congress enacted may not reflect the intent suggested in Congressional hearings, or it is possible that Congress's intent shifted between the hearings held by a prior Congress and the actual text enacted by a later Congress. ${ }^{[24]}$ Difficulties also arise in imputing to Congress the intent expressed in statements made by individuals (such as, for example, witnesses at congressional hearings) who are not members of Congress. Both the passage of time between the statements and the enactment of the 1976 Copyright Act, as well as the absence of direct statements by members of Congress supporting the "making available" right, suggest that the legislative history should not be used to create an ambiguity in statutory language that otherwise appears on its face to clearly identify "distribution" as the "distribution of copies or phonorecords to the public." 17 U.S.C. $\$ 106(3)$ (emphasis added). The language of 17 U.S.C. $\$ 106(3)$ ties the exclusive right to the distribution of copies or phonorecords, in contrast to the language describing the copyright owners' derivative works and public performance rights in 17 U.S.C. $\$ \S 106(2)$ and (4),

Restatement Council Draft No. 5 (2020) § 6.04, reporters' note d, at 113-14. The Howell parenthetical (referring to the "great weight of authority") is particularly misleading as it is directly contradicted by CD5's revision to Comment $d$.

244. [Ed. note: As we explained in comments, the final text of $\S 106(3)$ is the same as the $1965 \mathrm{draft}$ text Compare S. 1006, 89th Cong., A Bill for the General Revision of the Copyright Law, Title 17 of the U.S. Code, and for Other Purposes, reprinted in 8 OMNIBUS COPYRIGHT REVISION LEGISLATIVE HISTORY 3, 8 (2001) with 17 U.S.C. §106(3); see Menell, Copyright's Lost Ark, supra note 24, at 42-43. There is no legislative history supporting the notion that Congress shifted its position, and subsequent developments - including the language in the Sound Recording Amendments Act of 1971 and the Geneva Phonogram Treaty, see id. at 50-51, 59, reinforce the making the making available interpretation. Therefore, this comment not only finds no support in the pertinent materials, but is misleading.] 
respectively, which makes clear that those rights extend to the "work" and can be infringed without requiring the infringer to use or create any copy or phonorecord. ${ }^{245}$

Instead of supplying the actual legislative history or forthrightly addressing interpretive methodology, the draft now doubles down on its prior flawed position, committing itself to a wooden textualist position while purporting not to take a position. Without any supporting authority, the Restatement calls into question the scope of appropriate legislative history by noting that there are difficulties imputing to Congress the statements by its authorized agents (i.e., the Copyright Office), to which Congress entrusted drafting of the reforms. The suggestion that hearings and reports are not legislative history is clearly incorrect, as demonstrated by numerous Supreme Court decisions using those materials to interpret the Copyright Act. ${ }^{246}$ A prime example is the Court's unanimous decision in CCNV v. Reid, which relies on the legislative history for its interpretation, and in so doing looks to the Register's Supplemental Report and Copyright Law Revision Hearings to confirm its views. ${ }^{247}$ The suggestion that legislative history ought to be limited to "members of Congress" contradicts the Restatement's own extensive use of such sources elsewhere in CD5. ${ }^{248}$

Also disconcerting is the observation that legislative history "should not be used to create an ambiguity in statutory language" that is otherwise clear. ${ }^{249}$ Echoing the textualist critique of ambiguity in statutory language, ${ }^{250}$ this suggestion pretends that the text of the provision is unambiguous even though the dictionary definitions of key terms reveal multiple possible meanings, ${ }^{251}$ and by the draft's own admission the provision has produced evenly-split authorities. The provision is thus capable of more than one meaning, which is the dictionary definition of ambiguous.

CD5 exacerbates the fundamental mismatch between Restatements and statutes by exposing the incoherence that the failure to address statutory interpretation produces. Instead of explicating and dealing with the interpretive challenge underlying the making available right directly through the text and its accompanying legislative history, the Restatement prefers to hide behind incompletely-informed

245. Restatement Council Draft No. 5 (2020) § 6.04, reporters' note d, at 115-16.

246. See supra note 238 (listing numerous Supreme Court decisions relying on the very materials that $\mathrm{CD} 5$ dismisses). What is more frustrating is the failure of $\mathrm{CD} 5$ to provide the actual materials, which speaks for itself.

247. Cmty. for Creative Non-Violence v. Reid, 490 U.S. 730, $743-47$ (1989).

248. See supra note 236 and accompanying text. And it makes a hidden - and bold -interpretive choice in favor of a form of textualism that treats non-congressional legislative history as presumptively irrelevant. This was a position that Justice Scalia advocated, but was recognized to be a minority position. See, e.g., Wisconsin Pub. Intervenor v. Mortier, 501 U.S. 597, 617-23 (1991) (Scalia, J. concurring) ("[The majority's] only mistake was failing to recognize how unreliable Committee Reports are-not only as a genuine indicator of congressional intent but as a safe predictor of judicial construction."). The other eight justices took the opposite view on committee reports. See id. at 610 (majority opinion).

249. Restatement Council Draft No. 5 (2020) § 6.04, reporters' note d, at 116.

250. See, e.g., Brett M. Kavanaugh, Two Challenges for the Judge as Umpire: Statutory Ambiguity and Constitutional Exceptions, Keynote Address at the Federal Courts, Practice \& Procedure Symposium: Justice Scalia and the Federal Courts (Feb. 3, 2017), in 92 NOTRE DAME L. REV. 1907, 1910 (2017); John F. Manning, Textualism as a Nondelegation Doctrine, 97 CoLUM. L. REV. 673, 677-94 (1997).

251. See Menell, Copyright's Lost Ark, supra note 24, at 53-57, 60-61. 
case law; it showcases why statutory interpretation is clearly different from common law adjudication and requires a different restatement methodology.

\section{CONCLUSION: REMEDYING THE MISMATCH}

As originally conceived by the ALI's founders and adhered to ever since, the structure and orientation of the Restatements of Law are at odds with the role, nature, and significance of statutory law in the American legal landscape. It is principally for this reason that the ALI stayed away from areas of law dominated by uniform statutes, a reality that characterizes much of federal law. The Restatement of Copyright exposes this mismatch. Without reorientating its methodology, the project will not clarify or simplify U.S. copyright law. Rather, it will be seen as an unsystematic, subjective, and partisan effort to reform copyright law outside of the legislative process, which has already caused consternation in Congress and the Copyright Office, risks splintering the judiciary, and undermines the ALI's credibility.

The irony in all of this is that the fix to the problem has always been straightforward and very much aligned with the ALI's broader vision of bringing expert guidance to complex areas of law. If Restatements of statutory subjects such as copyright law aim to "provide guidance to the courts" by "provid[ing] the best interpretation of particular statutory provisions," 252 they need to first address the distinctiveness of statutory interpretation as a judicial function. They need to begin with a forthright recognition that "[s]tatutory texts are not just common law principles or aspirations to be shaped and applied as judges think reasonable."253 They should illuminate, and not mischaracterize, the legislative history that informs statutory interpretation. They should help judges to see that a host of institutional and prudential concerns shape that task. To that end, we herein describe three essential, but modest, proposals that will go a long way toward mitigating the mismatch.

\section{Appropriate Perspective}

In the traditional model, Restatements of common law areas purport to speak as a common law court would, adopting the perspective of an "excellent common-law judge." ${ }^{254}$ When simplistically extended to Restatements of statutory areas, this is sheer hubris. With very limited exceptions, when courts interpret statutes, they are not the primary lawmakers in that area of law. They see their task as ascertaining, explicating, and applying directives inherent in the statute. Even if judges disagree about the appropriate method of going about that task, they nevertheless uniformly agree that as a purely descriptive matter, this is in fact their role.

252. Revesz, Federal Statutes, supra note 33, at 3.

253. Brett M. Kavanaugh, Fixing Statutory Interpretation, 129 HARV. L. REV. 2118, 2135 (2016) (reviewing Robert A. KATZMANn, JUdGing STATUTES (2014)).

254. ALI, CAPTURING THE VOICE (2015), supra note 151, at 6. 
Given this reality, to speak to courts through the voice of another court-albeit an oracular law-clarifying one-misapprehends the enterprise of guiding judges in the task of statutory construction. Not only does this approach pretend to make courts primary lawmakers in the domain, contrary to courts' own self-conceptions of their role, but it also hides critical aspects of the institutional dynamic underlying the task of statutory interpretation. As is well known, U.S. courts are not bound by a unitary method of statutory interpretation. Different judges use different approaches, techniques, and sources to interpret the meaning of a statute and apply its directive to individual disputes. At times, these differences are dispositive of the issue since they greatly influence a judge's ultimate conclusion. Consequently, where a Restatement of statutory law speaks as a court, it masks the crucial choice of methodological framework and approach that a judge might choose to deploy in the exercise of statutory interpretation. And the fact that the reporters do not explain their interpretive approach and apply different approaches to different provisionsarguably based on the reporters' normative predilections - will inevitably produce additional confusion in the jurisprudence.

Whereas the text of a statute suggests the interpretive discretion that a court has in distilling its meaning and applying it, the choice of method that a court may deploy in so distilling that meaning is itself a first-order discretion that the law gives judges. One judge may choose to be a textualist and limit herself to the text of the provision, abjuring reliance on any other source. Another may look to legislative intent when the text is ambiguous, to be distilled from the legislative history of the statute. And a third may look to the objects and policy behind the provision to affix its meaning. That choice is a hallmark of modern American statutory interpretation, and when a Restatement purports to speak as a court engaged in interpretation, it denies judges who might choose to make use of the Restatement that very first-order discretion in interpretive method.

The solution, we suggest, is for Restatements of statutory law to aid judges in exercising their discretion through forthright explication of the materials that inform statutory interpretation. A legislature puts forward its directive in the text of the statute, and it routinely explicates the reason, structure, and verbiage of that directive in accompanying reports and materials that inform the choice of text. Such legislative history sometimes delegates interpretive aspects to an expert agency when its directives need to be specifically operationalized. It sometimes codifies judgemade law and authorizes courts to perpetuate the common law approach to the interpretation of that provision. A Restatement of a statutory area of law should therefore endeavor to equip an intelligent interpreter of the statute's directive with the sources and context that the legislature provided through the record of its legislative process, in order to help courts interpret and make sense of its statutory directives. While a statutory Restatement may eventually advance its view on the best interpretation of a statutory provision, it should begin by setting out the different sources and materials that a court will need in the execution of that task. And it should do so without taking away a court's first-order choice on method, and thus remain agnostic on a court's interpretive philosophy. This would allow judges- 
regardless of their interpretive methods - to focus on what they see as necessary to the interpretation of the statute.

The Restatement could also explain how different interpretive lenses would construe the statutory provision under consideration or discuss how prior courts interpreted the provision. The Restatement should not, as it has currently done with copyright law's distribution right, put its thumb on the scale, downplay the most pertinent legislative materials, or actively mislead courts about what counts as legislative history. This only undermines the enterprise.

\section{Updating the Restatement Template}

The proposal that we advanced in 2018 attempted to modify the ALI's existing format for Restatements by respecting judges' role in interpreting statutes and providing them with the background and materials that will aid their work. As noted, it was rejected without an open discussion. In that proposed format, we advanced two principal changes.

The first was in keeping with the idea put forth by the Lewis Report in 1924that the black letter law be replaced with the actual (and complete) text of the statutory provision being addressed, rather than a paraphrased or truncated version. ${ }^{255}$ To abbreviate, paraphrase, or translate the language of the provision without providing an interpreter with the actual, full text of the provision denies the centrality of the text to the interpretive exercise. All interpretation begins with the text of the statute, and so must a Restatement of statutory law.

The second proposed change updates Lewis's account to the modern realities of statutory interpretation. Whereas traditional Restatements move from the black letter law to comments and illustrations, we propose introducing an additional category: "Interpretation." This category would lay out the numerous sources of interpretation that are available to a judge attempting to make sense of the text in the context of the statute. Such material would trace the crafting of the provision at issue as well as the surrounding context. Depending on the particular legislative history, it might cover reports that fueled the legislative initiative, prior draft bills, hearings, studies, and reports elaborating on the statute's text, structure, rationale, and purposes, relevant agency interpretations, and finally, of course, the jurisprudence wherein courts had interpreted the provision, including whether they were aware of the pertinent materials. Special care must be taken to ensure that, in setting out the jurisprudence in the area, the Restatement explain the court's interpretive exercise rather than just its holding, since that is likely to be most helpful to future courts. The remainder of the Restatement, including its comments, illustrations, and reporters' notes should be adapted to align with the nature and goals of a statutory Restatement.

255. Lewis Report, supra note 13, at 358. 


\section{Contextualizing Preambular Language}

The final change that we propose is to provide courts with some general grounding in the manner in which the statute being restated was created. As its Reporter noted in pitching the Copyright Restatement Project and the Director of the ALI emphasized in announcing the project, relatively few federal judges are broadly knowledgeable about copyright law and the heavy demands on their time limit their ability to master its history, distinctive legislative character, and details.

As copyright scholars well know, the process by which the Copyright Act came into being was unusual in ways that are particularly pertinent to interpreting its meaning. The process began in 1955 with Congress funding thirty-four studies and delegating to the Copyright Office (an arm of Congress) the responsibility for drafting an omnibus reform act. The Register set forth a draft bill in $1961^{256}$ and convened a series of hearings with stakeholders to vet, revise, and fine-tune the bill. In fact, much of the Copyright Act of 1976 was drafted and finalized between 1961 and 1965. The emergence of cable television in the mid 1960s very much delayed the completion of the omnibus reform. This resulted in some interim legislation being passed, such as the Sound Recordings Amendments Act of 1971 to address the mounting problem of record piracy. ${ }^{257}$

Such background is critically important to judges seeking to understand and assess the crafting and rationale behind many key provisions of the Copyright Act. It explains why the Supreme Court's CCNV v. Reid decision devotes so much space to reviewing materials from the early to mid-1960s in interpreting the work made for hire provision. ${ }^{258}$ The final House and Senate Reports, coming more than a decade later, simply do not recreate that vital legislative history.

Providing such information in an objective way very much promotes the ALI's stated mission. This is an area where legal scholars can be especially useful to courts in faithfully carrying out their responsibilities.

Thus, the Copyright Restatement should educate the many lay judges who occasionally confront the Copyright Act with an objective primer on the history surrounding the crafting of the Copyright Act. It should clearly and concisely explain the continuing relevance of the 1909 Act for pre-1978 works, the long gestation surrounding the 1976 Act, the legislation relating to computer software, and the wave of more recent amendments relating to the digital age. This preamble would enable an interpreter to see- from the very outset - the role and imprint of the statute within the area of law being restated, as well as the potentially relevant tools and sources that could be used in interpreting its provisions.

256. See U.S. COPYRIGHT OfFICE, REPORT OF THE REGISTER OF COPYRIGHTS ON THE GENERAL REVISION OF THE U.S. COPYRIGHT LAW (July 1961).

257. See Pub. L. No. 92-140, 85 Stat. 391 (1971).

258. Cmty. for Creative Non-Violence v. Reid, 490 U.S. 730, 744-49 (1989). 